\title{
Modulation of Mutagen-Induced Genotoxicity by two Lesotho Medicinal Plants in Allium cepa $\mathrm{L}$
}

\author{
Asita O. Asita ${ }^{1}$, David H. Heisi ${ }^{1}$ \& Tumelo Tjale ${ }^{1}$ \\ ${ }^{1}$ Department of Biology, National University of Lesotho, P.O. Roma 180, Maseru 100, Lesotho, Southern Africa \\ Correspondence: Asita O. Asita, Department of Biology, National University of Lesotho, P.O. Roma 180, \\ Maseru 100, Lesotho, Southern Africa. Tel: 266-5221-3292. E-mail: aoasita@yahoo.co.uk, ao.asita@nul.1s
}

Received: June 27, 2015 Accepted: July 21, 2015 Online Published: July 23, 2015

doi:10.5539/enrr.v5n3p37 URL: http://dx.doi.org/10.5539/enrr.v5n3p37

\begin{abstract}
Methanolic extracts $\left(\mathrm{mg} \mathrm{mL}^{-1}\right)$ of Dicoma anomala $(0.0625,0.125,0.25)$, Chenopodium album $(0.078,0.156$, 0.313), used in traditional medicine in Lesotho, and Camellia sinensis $(0.1094,0.2085,0.44)$ were assessed for cytotoxicity, genotoxicity and modulation of Cyclophosphamide (CP $1.25 \mathrm{mg} \mathrm{mL}^{-1}$ ) - and EMS (0.25 mg $\mathrm{mL}^{-1}$ )-induced genotoxicity using the Allium cepa assay following 24 hours treatment. Cytotoxicity was measured by the mitotic index (MI). Genotoxicity (GT) was expressed as the number of aberrant mitotic cells per 100 mitotic cells. The MI and GT of test groups (triplicates), were compared with the negative (water) control group using t-test. Modulatory effect $(\mathrm{ME})$ was calculated as, $\mathrm{ME}(\%)=(1-(\mathrm{A}-\mathrm{B}) /(\mathrm{A}-\mathrm{C}) \times 100)-1$. A positive $\mathrm{ME}$ indicated an increase (synergism or potentiation) while a negative $\mathrm{ME}$ indicated a reduction (anti-genotoxicity) of mutagen-induced genotoxicity. The concentrations of $D$. anomala extract were cytotoxic and genotoxic. Mixtures of CP or EMS with the lower concentrations of D. anomala extract were more genotoxic than CP (250.50\% increase) or EMS (149.74 and $157.37 \%$ increase) or extracts alone. Only $0.313 \mathrm{mg}$ $\mathrm{mL}^{-1}$ of $C$. album extract was cytotoxic but none of the three concentrations was genotoxic. Mixtures of CP with extracts of C.album were cytotoxic. CP-induced genotoxicity was reduced $(55.18,68.36,57.40 \%)$ and EMS-induced genotoxicity was also reduced by low concentrations $(50.72,61.13 \%$ of C.album extract. However, $0.313 \mathrm{mg} \mathrm{mL}^{-1}$ C. album extract increased (236.75\%) EMS-induced genotoxicity. C. sinensis extracts and their mixtures with $\mathrm{CP}$ were not cytotoxic or genotoxic. CP-induced genotoxicity was reduced (63.61, 66.62, $78.64 \%$ ) but EMS-induced genotoxicity was increased (124.97, 4.48, 110.52\%) by C. sinensis extract.
\end{abstract}

Keywords: Dicoma anomala, Chenopodium album, Camellia sinensis, anti-genotoxicity, Cyclophosphamide, ethyl methanesulphonate.

\section{Introduction}

Different herbs and plants have been used for millennia by different cultures and peoples in traditional medicine to treat numerous diseases. It has been suggested in more recent times, that diets that have high fruit and vegetable content may help protect against cataracts, diabetes, Alzheimer's disease (Willett, 2002; Ames et al., 1993) and asthma (Woods et al., 2003). It was found in one study for instance, that people who consumed the highest amount of vegetables and fruits had a $20 \%$ lower risk of coronary heart disease and the lowest risks were observed in people who consumed more green leafy vegetables and fruits rich in vitamin C (Joshipura et al., 2001). Much of the protective effect of vegetables and fruits has been attributed to phytochemicals such as the carotenoids, flavonoids isoflavonoids and phenolic acids whose major role is protection against oxidation (Boyer \& Liu, 2004; Wong et al., 2012). Phytochemicals are thought to act as a proton sink that synergistically bring about the antioxidant and free radical scavenging potentials observed (Alisi et al., 2011; Ndhlala et al., 2013). Many studies have also shown that the consumption of naturally occurring compounds can modify the mutagenic and carcinogenic effects of environmental contaminants (Debisri \& Archana, 1996; Gimmler-Luz et al., 1999).

The benefits of vegetables and fruits not withstanding however, recent investigations have revealed that many plants used as food or in traditional medicine have mutagenic, cytotoxic and genotoxic effects in in vitro and in vivo assays (Higashimoto et al., 1993; Schimmer et al., 1994; Kassie et al., 1996; Çelik \& Aslantürk, 2007). Medicinal herbs have also been shown to cause adverse effects or have the potential to interact with other medications (Zink \& Chaffin, 1998). Many plants contain mutagenic and/or carcinogenic substances (Ames, 1986; de Sá Ferreira \& Ferrão Vargas, 1999) and their use has been correlated with high rate of tumor formation 
in some human populations (Wynder et al., 1983; Ames, 1986; Nagao et al., 1986; Nguyen et al., 1989; Brito et al., 1990), which raises concern about the potential mutagenic or genotoxic hazards that could result from the long-term use of such plants as food or medicine. For many of the plants used in traditional medicine, not enough information is available on their potential risk to health (Basaran et al., 1996).

The extracts of some plants have been observed to induce both mutagenic and antimutagenic effects on known mutagens in different test systems (Debisri \& Archana, 1996). The natural plant products that induce mutations and modify the action of other known mutagens on the living organisms do so by either, inactivating the existing mutagens within the cell (desmutagens), inhibiting the production of mutagens in the cell (bioantimutagens), synergizing the activity of existing mutagens (comutagens) or activating the promutagens within the cell into mutagens (Debisri \& Archana, 1996).

Two plant species commonly used in traditional medicine in Southern Africa are Dicoma anomala Sond (Hloenya in Sesotho) and Chenopodium album (Seruoe in Sesotho). D. anomala, common name fever bush or stomach bush, is an erect, sub-erect or prostrate perennial herb belonging to the family, Asteraceae. It bears aromatic semi-woody underground tubers at the base of a woody subterranean stem. Two subspecies of D. anomala occur in South Africa: D. anomala sub sp anomala and D. anomala subsp. gerrardii (Becker et al., 2011). Phytochemical investigations of $D$. anomala have identified several classes of secondary metabolites; including acetylenic compounds, phenolic acids, flavonoids, sesquiterpene lactones, triterpenes and phytosterols (Becker et al., 2011). Dicoma anomala is used as a root decoction for blood disorders, colic, diarrhoea, dysentery, toothache, and purgative for intestinal worms (Kazembe \& Chinyuku, 2012). Chenopodium album L. (family Chenopodiaceae, genus Chenopodium) is an annual shrub widely grown in Europe, North America, Asia, and Africa. It is commonly known as WhiteGoose foot, pigweed, fat hen or lamb-quarters' (Bailey, 1977; GRIN Database, 2005). Phytochemical analyses revealed the presence of alkaloids (Horio et al., 1993; Cutillo et al., 2004), apocarotenoids (DellaGreca et al., 2004), flavonoids (Gohar \& Elmazar, 1997), phytoecdysteroids (Dinan, 1992; Dinan et al., 1998; DellaGreca et al., 2005a) and an unusual xyloside (DellaGreca et al., 2005b) in the plant. Concoctions of the leaves are used in Lesotho for the treatment of abdominal pain, worm infection, pulmonary and nervous obstruction (Shale et al., 1999). Camellia sinensis (family Theaceae) is a plant that is native to mainland South and Southeast Asia, especially India and China (Ming, 1992). The leaves are used in the production of green tea. Green tea (non-fermented) is derived directly from drying and steaming of fresh tea leaves (Zuo et al., 2002). Green tea contains mainly polyphenolic catechins such as (-)-epicatechin, $(+)$-gallocatechin, $(+)$ catechin as well as gallic acid and caffeine, to which some of its beneficial effects have been attributed (Gupta et al., 2002). Camellia sinensis was included in the study so that it could be used for comparative analysis since its phytochemistry, antioxidant activity and biochemistry have been extensively studied (Buřičova \& Reblova, 2008).

Studies on agents that modulate carcinogen-induced genotoxic effects in experimental animals provide end points that can be used for assessing the antimutagenic or anticarcinogenic properties of putative chemopreventive compounds and for predicting their protective efficacy in humans (Khaidakov et al., 2001).

Cyclophosphamide (CP) is an antineoplastic drug that belongs to the nitrogen mustered family of alkylating agents which include chlorambucil and busulpfan which are used for the treatment of various cancers and some autoimmune diseases. These drugs work by interrupting the cell cycle by forming DNA cross linking, DNA lesions and mediates G0/G1 and S phase arrest (Baumann \& Preiss, 2001). Cyclophosphamide is an indirect-acting agent (promutagen) that is first oxidized by the microsomal cytochrome P450-linked enzyme to be further converted into its biologically reactive ultimate metabolites, acrolein, phosphoramide mustard and nornitrogen mustard. Phosphoramide mustard alkylates DNA (Mohn \& Ellenberger, 1976; Hales, 1982). At chromosomal level, CP causes chromosomal aberration and increase in frequency of sister chromatid exchange. It also causes apoptosis and cell toxicity (Panigrahy et al., 2011).

Ethyl methanesulphonate (EMS) is a colorless liquid used experimentally as a mutagen, tetratogen, and brain carcinogen and as a research chemical (Stubbs et al., 1997). EMS has been used in a wide variety of biological test systems in studies of mutation effects (Sega, 1984; Platzek et al., 1995; Bökel, 2008). EMS induces DNA damage by a direct mechanism, acting at various sites as a monofunctional ethylating agent of nucleotides (Müller et al., 2009).

The Allium cepa $\mathrm{L}$ assay is one of the established plant bioassays, validated by the international programme on chemical safety (IPCS, WHO), as an efficient and standard test for chemicals screening and in situ monitoring of the genotoxicity of environmental substances (Leme \& Marin-Morales, 2009). This plant bears a few chromosomes $(2 \mathrm{n}=16)$ that are large, which facilitates the evaluation of chromosome damages and/or 
disturbances in cell division cycle, including eventual aneuploidy risks (Grant, 1982; Fiskesjö, 1985; Leme \& Marin- Morales, 2008). Allium cepa is used to study basic mechanisms as well as the effects of environmental contaminants on cell division and chromosome. The results obtained from such studies, using the Allium cepa assay have been shown to be similar with those of mammalian and non-mammalian test systems (Constantin \& Owen 1982; Fiskesjö, 1985; Cauhan et al., 1999; Aydemir et al., 2008). Finally, plants have monooxygenase enzyme systems that are to a certain degree similar to the mammal monooxygenase enzyme complex, although the plant enzyme complex possesses a number of distinguishing characteristics (Plewa \& Gentile, 1982; Higashi, 1988). Onion root cells also have the ability to activate promutagens (the MFO-system) (Fiskesjö, 1985).

We are not aware of any published data on the genotoxic and antimutagenic effects of Dicoma anomala and Chenopodium album despite the fact that different parts of these plant species are widely used in traditional medicine. The purpose of this study was to assess the methanolic extracts of Dicoma anomala, Chenopodium album and, the refence Camellia sinensis (green tea) for cytotoxicity, genotoxicity and modulation of the genotoxicity induced by cyclophosphamide (CP) and Ethyl methanesulphonate (EMS) using the Allium cepa root meristem cells chromosome aberration assay system.

\section{Materials and Methods}

Test organism: Onion (Allium cepa) seeds: variety of Texas Grano 502 P.R.R. was a product of Sakata seeds, Lanseria 1748, Republic of South Africa and were purchased from Maseru garden centre, Lesotho, Southern Africa.

Mutagens and chemicals: Cyclophosphamide (CP) was a product of Sigma Chemical Company and Ethylmethane sulphonate was a product of Fluka. Methanol (Absolute) was a product of Associated Chemical Enterprises (PTY) LTD of The Republic of South Africa; Hydrochloric acid and Glacial acetic acid were products of UNILAB of The Republic of South Africa; Aceto-carmine stain from Carolina Biological Supply Company, USA.

Plant material and preparation of crude extracts: The plant parts used were as follows: Dicoma anomala (root), Chenopodium album (leaves) and Camellia sinensis (leaves). Dicoma anomala and Chenopodium album were collected from the outskirts of the National University of Lesotho, and authenticated by the curator of the Herbarium at the Department of Biology of university, where the voucher specimens of these plants have been deposited. Camellia sinensis (leaves) were purchased as green tea from a local Chinese shop as EVE'S GREEN TEA, LOT 13T-TO15, which was packed in China for Evergrow Import \& Export CC, T/A EVE'S TEA HOUSE, Emmarentia, Johannesburg, South Africa. The crude extracts were prepared according to the method of Adedapo et al. (2009), with slight modifications. Briefly, chopped and dried roots of Dicoma anomala were dried in an oven at $37^{\circ} \mathrm{C}$ for 48 hours and ground into powder. The leaves of Chenopodium album and Camellia sinensis were also dried and ground. The powders were stored in the refrigerator at $4^{\circ} \mathrm{C}$ until use. Extraction was carried out at $1 \mathrm{~g} 50 \mathrm{~mL}^{-1}$ of $98 \%$ methanol. The mixture was then shaken on the orbital shaker for $48 \mathrm{~h}$. The extract was filtered through No.1 Whatman filter paper (Whatman Ltd., England) using suction. The filtrates obtained were concentrated under vacuum in a rotary evaporator and oven dried at $35^{\circ} \mathrm{C}$ for 12 hours to constant weight and stored at $4^{\circ} \mathrm{C}$ in the refrigerator till used.

\subsection{Experiments to Select Concentrations of Plant Extracts to Use}

A preliminary dose selection experiment was conducted to determine the doses of test compounds i.e. CP, EMS and plant extract to be used in the actual experiments according to the method of Asita \& Makhalemele (2008). The $\mathrm{EC}_{50 \mathrm{~s}}(\mathrm{mg} / \mathrm{mL})$ values of the test compounds were approximately, CP (2.5); EMS (1.00); Dicoma anomala (1.5); Chenopodium album (1.25) and Camellia sinensis (1.75). The EC50s of the test compounds proved to be too toxic in trial experiments. The following concentrations $\left(\mathrm{mg} \mathrm{mL}^{-1}\right)$ of the mutagens and crude plant extracts were therefore used in the genotoxicity tests; CP (1.5); EMS (0.25), Dicoma anomala (0.0625, 0.125 and 0.25); Chenopodium album $(0.078,0.156$ and 0.313$)$ and Camellia sinensis $(0.1094,0.2085$ and 0.44$)$.

\subsection{Genotoxicity Assay}

The method used was similar to the method of Asita \& Makhalemele (2008). Alium cepa (onion) seeds were spread on water moistened filter paper in a petri dish, at room temperature $\left(22 \pm 2{ }^{\circ} \mathrm{C}\right)$, until they germinated (about 72 to 96 hours) and the radicles reached a length of about $2 \mathrm{~cm}$. Ten seedlings were transferred onto a filter paper kept moistened in a petri dish with CP $(1.5 \mathrm{mg} / \mathrm{mL})$, EMS $(0.25 \mathrm{mg} / \mathrm{mL})$, extracts of Dicoma anomala $(0.0625,0.125$ and 0.25$)$; Chenopodium album (0.078, 0.156 and 0.313$)$ and Camellia sinensis (0.1094, 0.2085 and 0.44 ) or mixtures of CP or EMS with each of the three different concentrations of each plant extract, for 24 hours at room temperature. Distilled water was used as a negative control. 
In one study, the methanolic extract of Trigonella foenum-graecum was more effective at reducing $\mathrm{CdSO}_{4}$-induced mutagenicity in the Allium sepa assay when roots were treated simultaneously with extracts and $\mathrm{CdSO}_{4}$ compared to separate treatments with extract first before mutagen or mutagen first before extract (Mekki, 2014).

\subsection{Root Harvest and Slide Preparation}

After 24 hours of exposure, three root tips from three seeds per dose were collected at random and assessed as described by Asita \& Makhalemele (2008). The slides were coded, viewed, using oil immersion, under the light microscope (Olympus CX 21) at 1000 x magnification and scored blind for normal and aberrant cells in the different stages of the cell cycle. The most representative ones for each structural aberration class were photographed using a Zeiss PrimoStar microscope mounted with Canon camera model, Power Shot A640.

\subsection{Scoring of Slides and Data Analysis}

\subsubsection{Scoring of Slides}

On each of three slides $(n=3)$ per treatment, a total of 2000 cells, classified into interphase or dividing cell i.e. Prophase (Normal, $\mathrm{N}$ or aberrant, $\mathrm{ABN})$; Metaphase $(\mathrm{N}$ or $\mathrm{ABN})$; Anaphase $(\mathrm{N}$ or $\mathrm{ABN})$ or Telophase $(\mathrm{N}$ or $\mathrm{ABN}$ ) were scored, i.e. a total of 6000 cells each for the control and treatment groups.

\subsubsection{Cytotoxicity}

The mitotic index (MI) was expressed as the number of dividing cells per 100 cells scored according to the formula:

$$
\text { MI = Number of dividing cells/Total number of cells scored } \mathrm{x} 100 .
$$

The MI was used as a measure of cytotoxicity (CT). The MI of each treatment group was compared with that of the negative control group using t-test at a probability level of 0.05 , using the SPSS for windows, version 11.0 software.

\subsubsection{Genotoxicity}

Genotoxicity (GT) was expressed as the number of aberrant mitotic cells (AMC) per 100 mitotic cells [i.e AMC + normal mitotic cells (NMC)] scored according to the formula:

$$
\text { Frequency of } \mathrm{AMC}(\%)=\mathrm{AMC} /(\mathrm{AMC}+\mathrm{NMC}) \times 100
$$

The percentage of aberrant mitotic cells (AMC) in each group of three slides per concentration of test agent was compared with that of the negative control group using t-test. $\mathrm{P}$ values less than $0.05(\mathrm{P}<0.05)$ were considered as indicative of significance.

\subsubsection{Modulatory Effect (ME) of Plant Extracts on Mutagen-Induced Genotoxicity}

The modulatory effect (ME) of plant extract on CP- or EMS-induced genotoxicity (GT) was calculated using a modified formula of Akeem et al. (2011):

$$
\mathrm{ME}(\%)=(1-(\mathrm{A}-\mathrm{B}) /(\mathrm{A}-\mathrm{C}) \times 100)-1
$$

Where, $\mathrm{ME}$ is the percentage reduction (ME is negative) or increase (ME is positive) of genotoxicity (GT); ' $\mathrm{A}$ ' is the frequency of GT induced by CP or EMS alone; ' $\mathrm{B}$ ' is the frequency of GT induced by each mixture of plant extract and $\mathrm{CP}$ or EMS and ' $\mathrm{C}$ ' is the frequency of GT induced by tap water alone.

A positive $(+)$ value of $\mathrm{ME}$ indicated that the mixture of mutagen and plant extract was more genotoxic than mutagen alone but may be more (synergism: if both extract and mutagen were mutagenic) or less (mutagen potentiation: if extract was not mutagenic) genotoxic than the plant extract alone. A negative (-) value of ME indicated that the mixture of mutagen and plant extract was less genotoxic than mutagen alone (anti-genotoxicity) but may be less (antagonism: if both extract and mutagen were genotoxic but mixture was not) or more (extract potentiation by mutagen if extract was not genotoxic) genotoxic than the plant extract alone.

\subsubsection{Data Analysis}

Data were expressed as mean \pm S.D. of three values. Differences between controls and treatment groups were determined using Student's t-test. P values of less than 0.05 were considered statistically significant.

\section{Results}

\subsection{Chromosome Aberrations}

Photographs of the most representative pictures of normal mitotic cells and cells containing the different types of chromosome aberrations that were observed and scored are presented in Figure 1. The aberrant dividing cells observed and scored contained the following types of aberrations: For treatments with D. anomala were sticky 
chromosomes (S) and c-mitosis (C-Mit); sticky chromosomes (S), c-mitosis (C-Mit), chromosome largards (L)., anaphase and telophase bridges (A.B) and chromosome breaks for treatments with C. album; sticky chromosomes (S), c-mitosis (C-Mit), chromosome largards (L)., anaphase and telophase bridges (A.B) and chromosome breaks for treatments with $C$. sinensis and EMS.
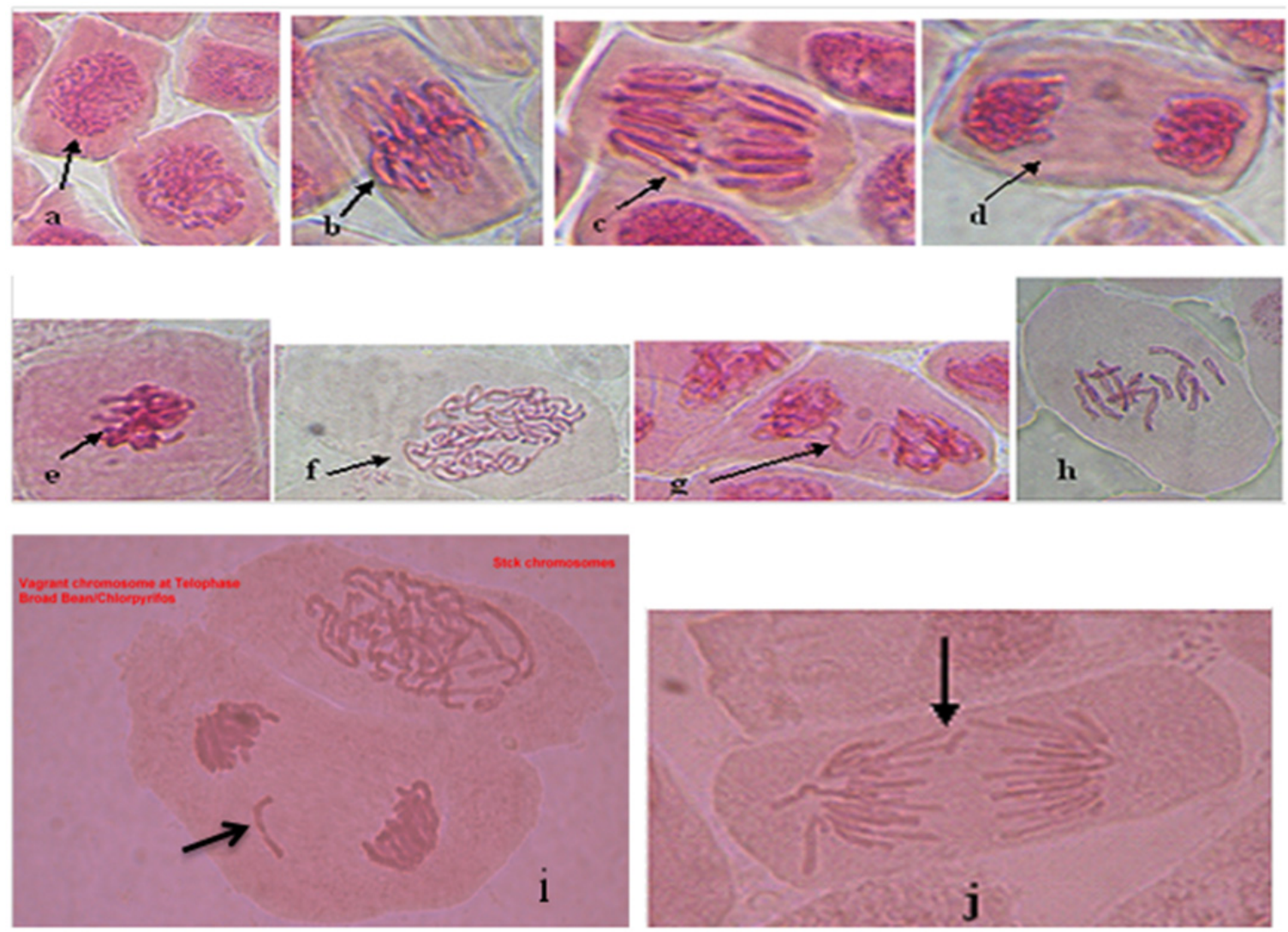

Figure 1. Photographs of cells of Allium cepa showing untreated cells in normal division stages and cells treated with mutagen, plant extract and mixtures of plant extract and mutagen showing the different types of chromosomal abnormalities observed. Magnification is 1000 X. (a) Normal prophase cell (b) Normal metaphase (c) Normal anaphase (d) Normal telophase (e) Sticky metaphase (f) sticky prophase cell (g) Chromosome bridge at telophase (h) C-mitosis (i) Vagrant or laggard chromosome (j) lagging chromosome fragment

\subsection{Cytotoxicity and Genotoxicity}

The results of the cytotoxicity and genotoxicity experiments with the extracts of the three different plants and the mutagens are presented in tables 1,2 and 3 . In table 4 is presented a summary of the information in Tables 1,2 and 3 .

\subsubsection{Cytotoxicity and Genotoxicity Analysis of D. Anomala Extract}

In Table 1 are the results of cytotoxicity and genotoxicity experiments with extract of D. anomala and the mutagens, $\mathrm{CP}$ and EMS.

$(P+M) /(A+T)$ Ratio: Examination of the $(\mathrm{P}+\mathrm{M}) /(\mathrm{A}+\mathrm{T})$ ratio in column 8 of Table 1 shows that the test agents, i.e. CP, EMS or different concentrations of $D$. anomala extract alone or their separate mixtures with CP or EMS, did not induce any significant change in the $(\mathrm{P}+\mathrm{M}) /(\mathrm{A}+\mathrm{T})$ ratio, when compared with the water treated negative control group $(\mathrm{P}>0.05)$.

Cytotoxicity: Examination of the MI in column 9 of table 1 shows that the concentration of $\mathrm{CP}\left(1.25 \mathrm{mg} \mathrm{mL}^{-1}\right)$ or EMS $\left(0.25 \mathrm{mg} \mathrm{mL}^{-1}\right)$ used was not toxic to the root meristem cells of $A$. sepa when compared to the water treated negative control $(\mathrm{P}>0.05)$. The two highest concentrations of $D$. anomala extract $\left(0.125\right.$ and $\left.0.25 \mathrm{mg} \mathrm{mL}^{-1}\right)$ were toxic $(\mathrm{P}<0.05)$. The mixture of $\mathrm{CP}$ separately with each of the three different concentrations of $D$. anomala 
extract was toxic to the root meristem cells $(\mathrm{P}<0.05)$. The mixture of EMS separately with the lowest $(0.0625$ $\left.\mathrm{mg} \mathrm{mL} \mathrm{m}^{-1}\right)$ or highest $\left(0.25 \mathrm{mg} \mathrm{mL}^{-1}\right)$ concentration of $D$. anomala extract was toxic to the root meristem cells $(\mathrm{P}$ $<0.05)$. The mixture of EMS separately with the middle $\left(0.125 \mathrm{mg} \mathrm{mL}^{-1}\right)$ concentration of plant extract was not toxic to the root meristem cells $(\mathrm{P}>0.05)$.

Genotoxicity (GT): Examination of induction of genotoxicity in column 10 of Table 1 shows that the concentration of CP $\left(1.25 \mathrm{mg} \mathrm{mL}^{-1}\right)$ or EMS $\left(0.25 \mathrm{mg} \mathrm{mL}^{-1}\right)$ used was genotoxic to the root meristem cells of $A$. sepa when compared to the water treated negative control $(\mathrm{P}<0.05)$. All three concentrations of $D$. anomala extract were genotoxic $(\mathrm{P}<0.05)$ and the genotoxicity was concentration dependent. The mixture of $\mathrm{CP}$ separately with each of the three different concentrations of $D$. anomala extract was genotoxic to the root meristem cells $(\mathrm{P}<0.05)$. Each mixture of EMS separately with each of the three different concentrations of plant extract was also genotoxic to the root meristem cells $(\mathrm{P}<0.05)$.

Table 1. Cytotoxicity and Genotoxicity of extract of $D$.anomala (root), EMS and CP to meristem cells of onion root tip and the Modulatory effects (ME) of D .anomala extracts (PE) on EMS- and CP-induced Genotoxicity

\begin{tabular}{|c|c|c|c|c|c|c|c|c|c|c|c|}
\hline \multirow{3}{*}{$\begin{array}{c}\mathrm{TC} \\
\text { concentration } \\
\left(\mathrm{mg} \mathrm{mL}^{-1}\right) \\
\text { \& Treatment }\end{array}$} & \multirow[b]{3}{*}{ Statistics } & \multicolumn{5}{|c|}{ Cells Scored } & \multirow[b]{3}{*}{$\begin{array}{l}(\mathrm{P}+\mathrm{M}) / \\
(\mathrm{A}+\mathrm{T})\end{array}$} & \multirow[b]{3}{*}{ MI } & \multirow[b]{3}{*}{$\begin{array}{c}\text { Genotoxi } \\
\text { city }\end{array}$} & \multirow{2}{*}{\multicolumn{2}{|c|}{ Modulatory Effect on Genotoxicity }} \\
\hline & & \multirow[b]{2}{*}{$\begin{array}{c}\text { Cells in } \\
\text { interphase }\end{array}$} & \multicolumn{3}{|c|}{ Cells in mitosis } & Total & & & & & \\
\hline & & & $\mathrm{N}$ & $\mathrm{ABN}$ & $\begin{array}{l}\text { Total cells } \\
\text { in mitosis }\end{array}$ & $\begin{array}{c}\text { Number } \\
\text { of Cells } \\
\text { Scored }\end{array}$ & & & & $\begin{array}{c}\text { Plant Extract } \\
\text { on } \mathrm{CP}\end{array}$ & $\begin{array}{c}\text { Plant Extract } \\
\text { on EMS }\end{array}$ \\
\hline \multirow{3}{*}{ Water } & MEAN & 1855.00 & 145.00 & 0.00 & 145.00 & 2000 & 3.02 & 7.25 & 0.00 & & \\
\hline & SD & 42.46 & 42.46 & 0.00 & 42.46 & 0 & 1.47 & 2.12 & 0.00 & & \\
\hline & MEAN & 1894.33 & 83.67 & 22.00 & 105.67 & 2000 & 3.83 & 5.28 & $22.05 \#$ & & \\
\hline \multirow[t]{2}{*}{$\mathrm{CP}(1.25)$} & $\mathrm{SD}$ & 38.03 & 34.93 & 5.57 & 38.03 & 0 & 3.50 & 1.90 & 5.95 & & \\
\hline & MEAN & 1892.00 & 80.67 & 27.33 & 108.00 & 2000 & 3.34 & 5.40 & $27.22 \#$ & & \\
\hline \multirow[t]{2}{*}{ EMS $(0.25)$} & SD & 24.76 & 34.02 & 13.80 & 24.76 & 0 & 0.26 & 1.24 & 18.27 & & \\
\hline & MEAN & 1852.00 & 115.67 & 32.33 & 148.00 & 2000 & 2.38 & 7.40 & $24.25 \#$ & & \\
\hline \multirow[t]{2}{*}{ PE (0.0625) } & SD & 34.18 & 49 & 14.84 & 34.65 & 0 & 0.10 & 1.71 & 15.65 & & \\
\hline & MEAN & 1952.33 & 19.67 & 28.00 & 47.67 & 2000.00 & 3.67 & $2.38^{*}$ & $62.30 \#$ & & \\
\hline \multirow[t]{2}{*}{$\mathrm{PE}(0.125)$} & SD & 32.88 & 17.39 & 21.93 & 32.88 & 0.00 & 1.37 & 1.64 & 37.16 & & \\
\hline & MEAN & 1947.00 & 0.67 & 52.33 & 53.00 & 2000.00 & 9.96 & $2.65 *$ & $99.05 \#$ & & \\
\hline PE (0.25) & SD & 17.00 & 1.15 & 16.01 & 17.00 & 0.00 & 9.72 & 0.85 & 1.65 & & \\
\hline $\mathrm{CP}+\mathrm{PE}$ & MEAN & 1961.33 & 10.00 & 28.67 & 38.67 & 2000.00 & 1.95 & $1.93^{*}$ & $77.29 \#$ & $251.50+\dagger$ & \\
\hline$(0.0625)$ & $\mathrm{SD}$ & 21.39 & 15.62 & 19.43 & 21.39 & 0.00 & 1.50 & 1.07 & 27.89 & & \\
\hline $\mathrm{CP}+\mathrm{PE}$ & MEAN & 1939.33 & 30.67 & 30.00 & 60.67 & 2000.00 & 3.30 & $3.03 *$ & $51.74 \#$ & $135.62 \dagger$ & \\
\hline \multirow[t]{2}{*}{$(0.125)$} & $\mathrm{SD}$ & 36.02 & 20.50 & 15.52 & 36.02 & 0.00 & 0.58 & 1.80 & 5.92 & & \\
\hline & MEAN & 1980.00 & 0.67 & 19.33 & 20.00 & 2000.00 & 3.43 & $1.00^{*}$ & $92.00 \#$ & $318.21 \dagger$ & \\
\hline $\mathrm{CP}+\mathrm{PE}(0.25)$ & SD & 13.23 & 0.58 & 13.61 & 13.23 & 0.00 & 0.99 & 0.66 & 10.58 & & \\
\hline $\mathrm{EMS}+\mathrm{PE}$ & MEAN & 1974.67 & 12.33 & 13.00 & 25.33 & 2000.00 & 2.06 & $1.27^{*}$ & $67.98 \#$ & & $150.74+\dagger$ \\
\hline$(0.0625)$ & $\mathrm{SD}$ & 16.44 & 18.01 & 2.00 & 16.44 & 0.00 & 0.27 & 0.82 & 38.68 & & \\
\hline $\mathrm{EMS}+\mathrm{PE}$ & MEAN & 1946.33 & 11.67 & 42.00 & 53.67 & 2000.00 & 2.28 & 2.68 & $70.06 \#$ & & $158.37+\dagger$ \\
\hline$(0.125)$ & SD & 61.78 & 10.02 & 53.02 & 61.78 & 0.00 & 0.62 & 3.09 & 27.19 & & \\
\hline $\mathrm{EMS}+\mathrm{PE}$ & MEAN & 1949.33 & 20.00 & 30.67 & 50.67 & 2000.00 & 3.35 & $2.53 *$ & $45.88 \#$ & & $69.55 \dagger$ \\
\hline$(0.25)$ & SD & 47.18 & 9.54 & 42.10 & 47.18 & 0.00 & 0.59 & 2.36 & 34.82 & & \\
\hline
\end{tabular}

$\mathrm{TC}=$ Test compound; $\mathrm{N}=$ Normal mitotic cells (comprising prophase, metaphase, anaphase and telophase); ABN $=$ Aberrant mitotic cells; $\mathrm{SD}=$ Standard deviation $; \mathrm{CP}=$ Cyclophosphamide; $\mathrm{EMS}=$ Ethylmethane sulphonate; $\mathrm{PE}$ $=$ Plant extract; $\mathrm{MI}=$ Mitotic index; $*=\mathrm{TC}$ is Toxic (MI treatment significantly different from negative control, $\mathrm{P}<0.05$ in the $\mathrm{t}$-test, $\mathrm{n}=3$ ); $\#=\mathrm{TC}$ is genotoxic (significant difference from negative control, $\mathrm{P}<0.05$ in the $\mathrm{t}$-test, $\mathrm{n}$ $=3) ; \dagger=\mathrm{PE}+$ Mutagen mixture more genotoxic than mutagen alone but more or less than $\mathrm{PE}$ alone; $+\dagger=\mathrm{PE}+$ Mutagen mixture more genotoxic than mutagen or PE alone; $t=\mathrm{PE}+$ Mutagen mixture less genotoxic than mutagen alone (reduction of genotoxicity) but more or less than PE alone; $+\ddagger=\mathrm{PE}+$ Mutagen mixture less genotoxic than mutagen or PE alone. 
Modulatory effect (ME) of plant extract on CP-induced Genotoxicity (GT): Examination of the ME in column 11 of Table 1 shows that the mixture of each concentration $\mathrm{m} \mathrm{mL}^{-1}$ ) of $D$. anomala extract with $\mathrm{CP}$ produced a positive value of ME $(0.0625=250.50 ; 0.125=134.62$ and $0.25=317.21)$. The mixtures were more genotoxic than the $\mathrm{CP}$ alone. In addition, the genotoxicity of the mixture of $\mathrm{CP}$ and the lowest concentration of $D$. anomala extract was greater than that of $\mathrm{CP}$ or plant extract alone. This observation suggests a synergistic effect of $\mathrm{CP}$ and $D$. anomala extract at low plant extract concentrations. However, the genotoxicity of the separate mixture of $\mathrm{CP}$ and the middle or top concentration of the plant extract was greater than that of $\mathrm{CP}$ alone but less than that of D. anomala extract alone.

Modulatory effect (ME) of plant extract on EMS-induced Genotoxicity (GT): Examination of the ME in column 12 of Table 1 shows that the mixture of each concentration $\left(\mathrm{mg} \mathrm{mL}^{-1}\right)$ of D. anomala extract and EMS produced a positive value of $\operatorname{ME}(0.0625=149.74 ; 0.125=157.37$ and $0.25=68.55)$. The mixtures were more genotoxic than the EMS alone. In addition, the genotoxicity of the mixture of EMS with the lowest or middle concentration of $D$. anomala extract was greater than that of EMS or $D$. anomala extract alone. This observation suggests a synergistic effect of EMS and the plant extract at low plant extract concentrations. However, the genotoxicity of the mixture of EMS and the highest concentration of the D. anomala extract was greater than that of EMS alone but less than that of the plant extract alone. It has to be noted that the middle and highest concentrations of $D$. anomala extracts and all $D$. anomala extract and mutagen mixtures were all toxic with low mitotic indices (MI).

\subsubsection{Cytotoxicity and Genotoxicity Analysis of C. album Extract}

In Table 2 are the results of cytotoxicity and genotoxicity experiments with extract of C. album and the mutagens, $\mathrm{CP}$ and EMS.

$(P+M) /(A+T)$ Ratio: Examination of the $(\mathrm{P}+\mathrm{M}) /(\mathrm{A}+\mathrm{T})$ ratio in column 8 of Table 2 shows that the test agents, i.e. CP, EMS, or different concentrations of C. album extract alone or their separate mixtures with $\mathrm{CP}$ or EMS, did not induce any significant change in the $(\mathrm{P}+\mathrm{M}) /(\mathrm{A}+\mathrm{T})$ ratio, when compared with the water treated negative control group $(\mathrm{P}>0.05)$.

Cytotoxicity: Examination of the MI in column 9 of Table 2 shows that the concentration $\left(\mathrm{mg} \mathrm{mL}^{-1}\right)$ of CP (1.25) or EMS (0.25) used was not toxic to the root meristem cells of $A$. sepa when compared to the water treated negative control $(\mathrm{P}>0.05)$. Only the highest concentration $\left(\mathrm{mg} \mathrm{mL}^{-1}\right)$ of $C$. album extract $(0.313)$ was toxic $(\mathrm{P}<0.05)$. Each separate mixture of $\mathrm{CP}$ with each of the three different concentrations of C. album extract was toxic to the root meristem cells. Each mixture of EMS separately with each of the three different concentrations of C. album extract was toxic to the root meristem cells $(\mathrm{P}<0.05)$.

Genotoxicity (GT): Examination of the induction of genotoxicity in column 10 of Table 2 shows that the concentration ( $\mathrm{mg} \mathrm{mL}^{-1}$ ) of CP (1.25) or EMS (0.25) used was genotoxic to the root meristem cells of $A$. sepa when compared to the water treated negative control $(\mathrm{P}<0.05)$. None of the three different concentrations of $C$. album extract was genotoxic $(\mathrm{P}>0.05)$ when compared to the water treated negative control group. None of the mixtures of CP separately with each of the three different concentrations of C. album extract was genotoxic to the root meristem cells $(\mathrm{P}>0.05)$. Only the mixture of EMS separately with the highest concentration of $C$. album extract $\left(0.313 \mathrm{mg} \mathrm{mL}^{-1}\right)$ was genotoxic to the root meristem cells $(\mathrm{P}<0.05)$.

Modulatory effect (ME) of plant extract on CP-induced Genotoxicity (GT): Examination of the ME in column 11 of Table 2 shows that the mixture of each concentration $\left(\mathrm{mg} \mathrm{mL}^{-1}\right)$ of $C$. album extract separately with $\mathrm{CP}$ produced a negative value of ME $(0.078=-55.18 ; 0.156=-68.36$ and $0.313=-57.40)$. Thus the mixtures were less genotoxic than $\mathrm{CP}$ alone. Because all the three concentrations of $C$. album extract and their individual mixtures with $\mathrm{CP}$ were not genotoxic, though $\mathrm{CP}$ alone was genetoxic, the results suggest the $C$. album extracts abolished the genotoxic effect of CP and was therefore exhibited anti-genotoxic effect to CP-induced genotoxicity.

Modulatory effect (ME) of plant extract on EMS-induced Genotoxicity (GT): Examination of the ME in column 12 of Table 2 shows that the mixture EMS with the lowest and middle concentrations $\left(\mathrm{mg} \mathrm{mL}^{-1}\right)$ of $C$. album extract were less genotoxic than EMS alone thereby producing negative ME values $(0.078=-50.72 ; 0.156=$ -61.13). However, the mixture of EMS with the highest concentration of $C$. album extract was more genotoxic than EMS alone thereby producing positive ME value $(0.313=236.75)$. The mixture of EMS and the lowest or middle concentration of $C$. album extract was not genotoxic when compared with the negative control in the t-test statistical analysis. Therefore the lowest and middle concentrations of C. album extract abolished the genotoxic effect of EMS in the mixtures and were therefore anti-genotoxic against EMS-induced genotoxicity. The mixture of EMS and the highest concentration of C. album extract was more genotoxicity than EMS or $C$. album extract alone, which suggested a synergistic effect of EMS and the C. album extract at high concentrations. 
Table 2. Cytotoxicity and Genotoxicity of extract of C. album (leaves), EMS and CP to meristem cells of onion root tip and the Modulatory effects (ME) of C. album extracts (PE) on EMS- and CP-induced Genotoxicity

\begin{tabular}{|c|c|c|c|c|c|c|c|c|c|c|c|}
\hline \multirow{3}{*}{$\begin{array}{c}\text { TC concentration } \\
\qquad\left(\mathrm{mg} \mathrm{mL}^{-1}\right) \\
\& \text { Treatment }\end{array}$} & \multirow[b]{3}{*}{ Statistics } & \multicolumn{5}{|c|}{ Cells Scored } & \multirow[b]{3}{*}{$(\mathrm{P}+\mathrm{M}) /(\mathrm{A}+\mathrm{T})$} & \multirow[b]{3}{*}{ MI } & \multirow[b]{3}{*}{$\begin{array}{l}\text { Genotoxi } \\
\text { city }\end{array}$} & \multirow{2}{*}{\multicolumn{2}{|c|}{ Modulatory Effect on Genotoxicity }} \\
\hline & & \multirow[b]{2}{*}{ Cells in interphase } & \multicolumn{3}{|c|}{ Cells in mitosis } & \multirow[b]{2}{*}{$\begin{array}{l}\text { Total Number } \\
\text { of Cells Scored }\end{array}$} & & & & & \\
\hline & & & $\mathrm{N}$ & ABN & $\begin{array}{l}\text { Total cells } \\
\text { in mitosis }\end{array}$ & & & & & $\begin{array}{c}\text { Plant Extract } \\
\text { on } \mathrm{CP}\end{array}$ & $\begin{array}{c}\text { Plant Extract } \\
\text { on EMS }\end{array}$ \\
\hline & MEAN & 1855.00 & 145.00 & 0.00 & 145.00 & 2000.00 & 3.02 & 7.25 & 0.00 & & \\
\hline \multirow[t]{2}{*}{ Water } & SD & 42.46 & 42.46 & 0.00 & 42.46 & 0.00 & 1.47 & 2.12 & 0.00 & & \\
\hline & MEAN & 1894.33 & 83.67 & 22.00 & 105.67 & 2000.00 & 3.83 & 5.28 & $22.05 \#$ & & \\
\hline \multirow[t]{2}{*}{$\mathrm{CP}(1.25)$} & SD & 38.03 & 34.93 & 5.57 & 38.03 & 0.00 & 3.50 & 1.90 & 5.95 & & \\
\hline & MEAN & 1892.00 & 80.67 & 27.33 & 108.00 & 2000.00 & 3.34 & 5.40 & $27.22 \#$ & & \\
\hline \multirow[t]{2}{*}{ EMS $(0.25)$} & SD & 24.76 & 34.02 & 13.80 & 24.76 & 0.00 & 0.26 & 1.24 & 18.27 & & \\
\hline & MEAN & 1880.33 & 117.67 & 2.00 & 119.67 & 2000.00 & 7.48 & 5.98 & 2.94 & & \\
\hline \multirow[t]{2}{*}{ PE (0.078) } & SD & 45.37 & 48.79 & 3.46 & 45.37 & 0.00 & 7.38 & 2.27 & 5.09 & & \\
\hline & MEAN & 1893.67 & 86.33 & 20.00 & 106.33 & 2000.00 & 3.05 & 5.32 & 19.77 & & \\
\hline \multirow[t]{2}{*}{$\mathrm{PE}(0.156)$} & SD & 21.20 & 40.27 & 29.60 & 21.20 & 0.00 & 1.46 & 1.06 & 28.49 & & \\
\hline & MEAN & 1973.00 & 27.00 & 0.00 & 27.00 & 2000.00 & 7.73 & $1.35^{*}$ & 0.00 & & \\
\hline \multirow[t]{2}{*}{$\operatorname{PE}(0.313)$} & SD & 14.73 & 14.73 & 0.00 & 14.73 & 0.00 & 8.08 & 0.74 & 0.00 & & \\
\hline & MEAN & 1966.33 & 31.33 & 2.33 & 33.67 & 2000 & 13.78 & $1.68^{*}$ & 9.88 & $-54.18 \ddagger$ & \\
\hline \multirow[t]{2}{*}{$\mathrm{CP}+\mathrm{PE}(0.078)$} & SD & 22.85 & 23.44 & 2.52 & 22.85 & 0 & 10.02 & 1.14 & 14.33 & & \\
\hline & MEAN & 1972 & 25 & 3 & 28 & 2000 & 9.71 & $1.4^{*}$ & 6.98 & $-67.36 \ddagger$ & \\
\hline \multirow[t]{2}{*}{$\mathrm{CP}+\mathrm{PE}(0.156)$} & SD & 17.35 & 13.89 & 5.2 & 17.35 & 0 & 4.97 & 0.87 & 12.08 & & \\
\hline & MEAN & 1988 & 11 & 1 & 12 & 2000 & 8.78 & $0.6^{*}$ & 9.39 & $-56.40 \%$ & \\
\hline \multirow[t]{2}{*}{$\mathrm{CP}+\mathrm{PE}(0.313)$} & SD & 2.65 & 3.46 & 1 & 2.65 & 0 & 5.34 & 0.13 & 9.11 & & \\
\hline & MEAN & 1943.33 & 48.00 & 8.67 & 56.67 & 2000.00 & 13.65 & $2.83^{*}$ & 13.41 & & $-49.72 \nLeftarrow$ \\
\hline \multirow[t]{2}{*}{ EMS + PE (0.078) } & SD & 52.94 & 45.21 & 8.50 & 52.94 & 0.00 & 18.50 & 2.65 & 12.89 & & \\
\hline & MEAN & 1974.00 & 22.67 & 3.33 & 26.00 & 2000.00 & 10.00 & $1.30^{*}$ & 10.58 & & -60.13 \\
\hline \multirow[t]{2}{*}{ EMS + PE $(0.156)$} & SD & 22.65 & 20.40 & 2.89 & 22.65 & 0.00 & 10.39 & 1.13 & 10.88 & & \\
\hline & MEAN & 1996.00 & 0.67 & 3.33 & 4.00 & 2000.00 & 3.67 & $0.20^{*}$ & $91.67 \#$ & & $237.75+\dagger$ \\
\hline EMS + PE (0.313) & SD & 3.61 & 1.15 & 2.52 & 3.61 & 0.00 & 3.79 & 0.18 & 14.43 & & \\
\hline
\end{tabular}

$\mathrm{TC}=$ Test compound; $\mathrm{N}=$ Normal mitotic cells (comprising prophase, metaphase, anaphase and telophase); ABN $=$ Aberrant mitotic cells; $\mathrm{SD}=$ Standard deviation $; \mathrm{CP}=$ Cyclophosphamide; $\mathrm{EMS}=$ Ethylmethane sulphonate; $\mathrm{PE}$ $=$ Plant extract MI = Mitotic index; $*=$ TC is Toxic (MI treatment significantly different from negative control, $\mathrm{P}<0.05$ in the t-test, $\mathrm{n}=3$ ); $\#=\mathrm{TC}$ is genotoxic (significant difference from negative control, $\mathrm{P}<0.05$ in the $\mathrm{t}$-test, $\mathrm{n}$ $=3) ; \dagger=\mathrm{PE}+$ Mutagen mixture more genotoxic than mutagen alone but more or less than $\mathrm{PE}$ alone; $+\dagger=\mathrm{PE}+$ Mutagen mixture more genotoxic than mutagen or PE alone; $\ddagger=\mathrm{PE}+$ Mutagen mixture less genotoxic than mutagen alone (reduction of genotoxicity) but more or less than PE alone; $+\ddagger=\mathrm{PE}+$ Mutagen mixture less genotoxic than mutagen or PE alone.

\subsubsection{Cytotoxicity and Genotoxicity Analysis of $C$. sinensis Extract}

In Table 3 are the results of cytotoxicity and genotoxicity experiments with extract of $C$. sinensis and the mutagens, CP and EMS.

$(P+M) /(A+T)$ Ratio: Examination of the $(\mathrm{P}+\mathrm{M}) /(\mathrm{A}+\mathrm{T})$ ratio in column 8 of Table 3 shows that the test agents, i.e. CP, EMS, $C$. sinensis extracts and separate mixtures of CP or EMS with either of the three different concentrations of $C$. sinensis extract, did not induce any significant reduction in the $(\mathrm{P}+\mathrm{M}) /(\mathrm{A}+\mathrm{T})$ ratio, when compared with the water treated negative control group $(\mathrm{P}>0.05)$. 
Table 3. Cytotoxicity and Genotoxicity of extract of $C$ sinensis (leaves), EMS and CP to meristem cells of onion root tip and the Modulatory effects (ME) of $C$ sinensis extract (PE) on EMS- and CP-induced Genotoxicity

\begin{tabular}{|c|c|c|c|c|c|c|c|c|c|c|c|}
\hline \multirow{3}{*}{$\begin{array}{c}\mathrm{TC} \\
\text { concentration } \\
\left(\mathrm{mg} \mathrm{mL}^{-1}\right) \& \\
\text { Treatment }\end{array}$} & \multirow[b]{3}{*}{ Statistic } & \multicolumn{5}{|c|}{ Cells Scored } & \multirow[b]{3}{*}{$\begin{array}{l}(\mathrm{P}+\mathrm{M}) / \\
(\mathrm{A}+\mathrm{T})\end{array}$} & \multirow[b]{3}{*}{ MI } & \multirow[b]{3}{*}{$\begin{array}{c}\text { Genotoxi } \\
\text { city }\end{array}$} & \multirow{2}{*}{\multicolumn{2}{|c|}{ Modulatory Effect on Genotoxicity }} \\
\hline & & & & Is in mi & & Total & & & & & \\
\hline & & $\begin{array}{c}\text { Cells in } \\
\text { interphase }\end{array}$ & $\mathrm{N}$ & ABN & $\begin{array}{c}\text { Total } \\
\text { number }\end{array}$ & $\begin{array}{l}\text { of Cells } \\
\text { Scored }\end{array}$ & & & & Plant Extract on CP & Plant Extract on EMS \\
\hline \multirow{3}{*}{ Water } & MEAN & 1855.00 & 144.67 & 0 & 144.67 & 2000 & 3.02 & 7.23 & 0.00 & & \\
\hline & SD & 42.46 & 42.77 & 0 & 42.77 & 0 & 1.47 & 2.14 & 0.00 & & \\
\hline & MEAN & 1894.33 & 83.33 & 22 & 105.33 & 2000 & 3.83 & 5.27 & $22.20 \#$ & & \\
\hline \multirow[t]{2}{*}{ СР (1.25) } & SD & 38.03 & 35.47 & 5.57 & 38.59 & 0 & 3.5 & 1.93 & 6.13 & & \\
\hline & MEAN & 1892.00 & 80.33 & 27.33 & 107.67 & 2000 & 3.34 & 5.38 & $27.40 \#$ & & \\
\hline \multirow[t]{2}{*}{ EMS $(0.25)$} & SD & 24.76 & 34.53 & 13.8 & 25.15 & 0 & 0.26 & 1.26 & 18.59 & & \\
\hline & MEAN & 1880.67 & 117.33 & 2 & 119.33 & 2000 & 3.08 & 5.97 & 2.13 & & \\
\hline \multirow[t]{2}{*}{ PE (0.1094) } & SD & 17.01 & 20.43 & 3.46 & 17.01 & 0 & 0.12 & 0.85 & 3.69 & & \\
\hline & MEAN & 1914.67 & 68.67 & 16.67 & 85.33 & 2000 & 4.14 & 4.27 & 2.25 & & \\
\hline \multirow[t]{2}{*}{ PE (0.2085) } & SD & 33.65 & 33.13 & 0.58 & 33.65 & 0 & 0.96 & 1.68 & 2.23 & & \\
\hline & MEAN & 1936.67 & 56.67 & 6.67 & 63.33 & 2000 & 5.05 & 3.17 & 7.70 & & \\
\hline PE (0.44) & SD & 50.85 & 51 & 9.87 & 50.85 & 0 & 2.65 & 2.54 & 7.21 & & \\
\hline $\mathrm{CP}+\mathrm{PE}$ & MEAN & 1881.00 & 108.67 & 10.33 & 119 & 2000 & 4.23 & 5.95 & 8.02 & $-62.61 \%$ & \\
\hline$(0.1094)$ & SD & 10.44 & 25.81 & 15.37 & 10.44 & 0 & 1.13 & 0.52 & 11.82 & & \\
\hline $\mathrm{CP}+\mathrm{PE}$ & MEAN & 1877.67 & 113.67 & 8.67 & 122.33 & 2000 & 4.17 & 6.12 & 7.36 & $-65.62 \%$ & \\
\hline \multirow[t]{2}{*}{$(0.2085)$} & SD & 15.50 & 7.23 & 8.62 & 15.5 & 0 & 0.29 & 0.78 & 6.97 & & \\
\hline & MEAN & 1919.67 & 77 & 3.33 & 80.33 & 2000 & 4.61 & 4.02 & 4.71 & $-77.64 \$$ & \\
\hline $\mathrm{CP}+\mathrm{PE}(0.44)$ & SD & 39.63 & 38.43 & 2.89 & 39.63 & 0 & 1.20 & 1.98 & 5.03 & & \\
\hline EMS + PE & MEAN & 1958.67 & 27.33 & 14 & 41.33 & 2000 & 3.80 & $2.07 *$ & $61.24 \#$ & & $125.97 \dagger$ \\
\hline$(0.1094)$ & SD & 24.01 & 11.93 & 14 & 24.01 & 0 & 1.97 & 1.20 & 26.70 & & \\
\hline $\mathrm{EMS}+\mathrm{PE}$ & MEAN & 1924.67 & 59.33 & 16 & 75.33 & 2000 & 4.17 & 3.77 & $28.44 \#$ & & $5.48 \dagger$ \\
\hline$(0.2085)$ & SD & 53.82 & 45.52 & 12.53 & 53.82 & 0 & 2.52 & 2.69 & 15.49 & & \\
\hline EMS + PE & MEAN & 1956.67 & 32.33 & 11 & 43.33 & 2000 & 5.94 & $2.17^{*}$ & $57.31 \#$ & & $111.52 \dagger$ \\
\hline$(0.44)$ & SD & 39.55 & 35.28 & 4.58 & 39.55 & 0 & 2.66 & 1.98 & 39.55 & & \\
\hline
\end{tabular}

$\mathrm{TC}=$ Test compound; $\mathrm{N}=$ Normal mitotic cells (comprising prophase, metaphase, anaphase and telophase); $\mathrm{ABN}$ $=$ Aberrant mitotic cells; $\mathrm{SD}=$ Standard deviation; $\mathrm{CP}=$ Cyclophosphamide; $\mathrm{EMS}=$ Ethylmethane sulphonate; $\mathrm{PE}$ $=$ Plant extract; $\mathrm{MI}=$ Mitotic index; ${ }^{*}=\mathrm{TC}$ is Toxic (MI treatment significantly different from negative control, $\mathrm{P}<0.05$ in the $\mathrm{t}$-test, $\mathrm{n}=3$ ); $\#=\mathrm{TC}$ is genotoxic (significant difference from negative control, $\mathrm{P}<0.05$ in the $\mathrm{t}$-test, $\mathrm{n}$ $=3) ; \dagger=\mathrm{PE}+$ Mutagen mixture more genotoxic than mutagen alone but more or less than PE alone; $+\dagger=\mathrm{PE}+$ Mutagen mixture more genotoxic than mutagen or PE alone; $t=\mathrm{PE}+$ Mutagen mixture less genotoxic than mutagen alone (reduction of genotoxicity) but more or less than PE alone; $+\$=\mathrm{PE}+$ Mutagen mixture less genotoxic than mutagen or PE alone.

Cytotoxicity: Examination of the MI in column 9 of Table 3 shows that the concentration $\left(\mathrm{mg} \mathrm{mL}^{-1}\right)$ of CP (1.25) or EMS (0.25) used was not toxic to the root meristem cells of $A$. sepa when compared to the water treated negative control $(\mathrm{P}>0.05)$. All three concentrations $\left(\mathrm{mg} \mathrm{mL}^{-1}\right)$ of $C$. sinensis extract (i.e. $0.1094,0.2085$ and 0.44$)$ were not toxic $(\mathrm{P}>0.05)$. Each separate mixture of $\mathrm{CP}$ with each of the three different concentrations of $C$. sinensis extract was not toxic to the root meristem cells $(\mathrm{P}>0.05)$. The mixture of EMS separately with the lowest $\left(0.1094 \mathrm{mg} \mathrm{mL}^{-1}\right)$ and the highest $\left(0.44 \mathrm{mg} \mathrm{mL}^{-1}\right)$ concentration of $C$. sinensis extract were cytotoxic $(\mathrm{P}<0.05)$.

Genotoxicity (GT): Examination of the induction of genotoxicity in column 10 of Table 3 shows that the concentration $\left(\mathrm{mg} \mathrm{mL}^{-1}\right)$ of CP (1.25) or EMS (0.25) used was genotoxic to the root meristem cells of A. sepa when compared to the water treated negative control $(\mathrm{P}<0.05)$. All the three concentrations $\left(\mathrm{mg} \mathrm{mL}^{-1}\right)(0.1094$, 0.2085 and 0.44$)$ of $C$. sinensis extracts were not genotoxic $(\mathrm{P}<0.05)$ when compared to the water treated negative control group. The mixtures of $C$. sinensis extract with $\mathrm{CP}$ separately were also not genotoxic to the 
root meristem cells $(\mathrm{P}>0.05)$. However, the mixtures of EMS separately with each of the three concentrations of $C$. sinensis extract were genotoxic to the root meristem cells $(\mathrm{P}<0.05)$.

Modulatory effect (ME) of plant extract on CP-induced Genotoxicity (GT): Examination of the ME in column 11 of Table 3 shows that the mixture of each concentration $\left(\mathrm{mg} \mathrm{mL}^{-1}\right)$ of $C$. sinensis extract separately with $\mathrm{CP}$ produced a negative value of ME $(0.1094=-63.61 ; 0.2085=-66.62$ and $0.44=-78.64)$. Thus the mixtures were less genotoxic than $\mathrm{CP}$ alone. Because all the three concentrations of $C$. sinensis extract and their individual mixtures with $\mathrm{CP}$ were not genotoxic, though $\mathrm{CP}$ alone was genetoxic, the results suggested that the $C$. sinensis extract abolished CP-induced genotoxicity and therefore exerted an anti-genotoxic effect on CP-induced genotoxicity.

Modulatory effect (ME) of plant extract on EMS-induced Genotoxicity (GT): Examination of the ME in column 12 of Table 3 shows that the mixtures were more genotoxic than EMS alone thereby producing positive ME values $\left(0.1094 \mathrm{mg} \mathrm{mL}^{-1}=124.97 ; 0.2085 \mathrm{mg} \mathrm{mL}^{-1}=4.48\right.$ and $\left.0.44 \mathrm{mg} \mathrm{mL}^{-1}=110.52\right)$. Because the mixtures were more genotoxic than EMS or C. sinensis extract alone, it suggested a potentiation of EMS-induced genotoxic effect since $C$. sinensis extracts were not genotoxic.

\section{Discussion}

The interest in plant-based pharmaceuticals that intensified due to the development of methods of screening for anticarcinogenic drugs (Hartwell, 1967) resulted in the extension of the survey to include plant extracts and plant products able to modify the process of mutagenesis, because of the observation of a correlation between carcinogenesis and mutagenesis (Debisri \& Archana, 1996). In this study the methanolic extracts of two plants used in traditional medicine in Lesotho, namely, Dicoma anomala (root), family, Asteraceae and Chenopodium album (leaves), family Chenopodiaceae, were evaluated for cytotoxicity, genotoxicity and modulatory effects on the genotoxicity induced by the direct acting mutagen, Ethyl methanesulphonate (EMS) and the indirect acting mutagen, Cyclophosphamide (CP), using the onion (Allium cepa L.) root tip meristem chromosome aberration assay system. The methanolic extract of Camellia sinensis (green tea) were also evaluated for comparison.

The results of the present study are summarized inTable 4 .

The concentrations of CP $\left(1.25 \mathrm{mg} \mathrm{mL}^{-1}\right)$ and EMS $\left(0.25 \mathrm{mg} \mathrm{mL}^{-1}\right)$ used in the present study reduced the mitotic index (MI) of treated roots but the decreases were not significant $(\mathrm{P}>0.05)$ and were adjudged not cytotoxic. They were however genotoxic to the root meristem cells of $A$. sepa when compared to the water treated negative control $(\mathrm{P}<0.05)$. EMS at a concentration of $2 \times 10^{-2} \mathrm{M}\left(0.2484 \mathrm{mg} \mathrm{mL}^{-1}\right)$ was however both toxic and mutagenic to root meristem cells of Allium cepa (Çelik \& Aslantürk, 2010). CP at a concentration of $1 \%\left(1 \mathrm{mg} \mathrm{mL}^{-1}\right.$ ) was also both toxic, i.e. significantly reduced the mitotic index (MI) and clastogenic, significantly induced chromosome aberrations, in treated onion root meristem cells (Akeem et al., 2011).

The three concentrations $\left(0.0625,0.125,0.25 \mathrm{mg} \mathrm{mL}^{-1}\right)$ of Dicoma anomala tested were cytotoxic and genotoxic to the onion root meristem cells. Many plant extracts including betel and tobacco leaf extracts demonstrated cytotoxicity to root-tip cells of Allium cepa (Sopova et al., 1983; Abraham \& Cherian, 1978). Methanolic extracts of another Asteraceae species, Schkuhria pinnata (Lam.) used in traditional medicine to treat eye infections, Pneumonia and diarrhea in South Africa was not mutagenic in the Salmonella microsome assay against Salmonella typhimurium tester strain TA98 but showed antibacterial activity (Luseba et al., 2007). The mixture of CP (1.25 mg $\mathrm{mL}^{-1}$ ) with each concentration of extract of Dicoma anomala separately was cytotoxic and genotoxic to the root tip meristem cells. The mixture of $\mathrm{CP}$ with each of the three concentrations of $D$. anomala was more genotoxic than CP alone (250.50, 134.62, and 317.21 \% increase). In addition, the mixture of CP with the lowest concentration was also more genotoxic than the Dicoma anomala extract alone. These observations suggested a synergistic interaction between CP and Dicoma anomala extract at low concentration but not at the higher concentrations. Crude methanolic extract $\left(1.2 \mathrm{mg} \mathrm{mL}^{-1}\right)$ of Dicoma anomala moderately inhibited cytochrome $\mathrm{P} 450$ (CYP) isoforms in in vitro tests using human liver microsomes (Gwaza et al., 2009). However, the plant monooxygenase enzyme complex is slightly different from the animal one (Plewa \& Gentile, 1982; Higashi, 1988). Therefore, although cyclophosphamide is a promutagen (Mohn \& Ellenberger, 1976; Hales, 1982), onion root cells have the ability to activate promutagens (Fiskesjö, 1985), which may have partly contributed to the results observed in the present study. The mixture of EMS $\left(0.25 \mathrm{mg} \mathrm{mL}^{-1}\right)$ with each concentration of extract of Dicoma anomala separately was genotoxic. The mixtures of EMS with the lowest and highest concentrations were in addition, also cytotoxic. The cytotoxicity was therefore not dose dependent. The mixture of EMS with each of the three concentrations of $D$. anomala extract was more genotoxic than EMS alone (149.74, 157.37 and $68.55 \%$ increase). In addition, the mixture of EMS with the lower concentrations of $D$ anomala extract was also more genotoxic than Dicoma anomala extract alone. These observations suggested a synergistic interaction between EMS and the Dicoma anomala extract at low concentrations but not at higher concentrations. 
Table 4. Summary of the cytotoxic, genotoxic and modulatory effects on CP- \& EMS-induced genotoxicity by $D$. anomala, $C$. album and the reference $C$. sinensis extracts in tests with Allium cepa root meristem cells

\begin{tabular}{|c|c|c|c|c|c|c|}
\hline \multirow[b]{2}{*}{ Test Compound } & \multirow{2}{*}{$\begin{array}{l}\text { Concentration } \\
\left(\mathrm{mg} \mathrm{mL}^{-1}\right)\end{array}$} & \multirow[b]{2}{*}{$(\mathrm{P}+\mathrm{M}) / \mathrm{A}+\mathrm{T})$} & \multirow[b]{2}{*}{ MI } & \multirow[b]{2}{*}{ Genotoxicity } & \multicolumn{2}{|c|}{$\begin{array}{l}\text { Modulatory Effect on Genotoxicity (\% reduction or } \\
\text { increase of mutagen-induced GT) }\end{array}$} \\
\hline & & & & & Plant Extract on CP & Plant Extract on EMS \\
\hline $\mathrm{CP}$ & 1.25 & ns & $\mathrm{nt}$ & $\#$ & & \\
\hline EMS & 0.25 & ns & $\mathrm{nt}$ & \# & & \\
\hline D. anomala & 0.0625 & ns & $\mathrm{nt}$ & $\#$ & & \\
\hline D. anomala & 0.125 & ns & $*$ & $\#$ & & \\
\hline D. anomala & 0.25 & ns & $*$ & $\#$ & & \\
\hline D. anomala $+\mathrm{CP}$ & $0.0625+1.25$ & $\mathrm{~ns}$ & $*$ & \# & $251.50+\dagger$ & \\
\hline D. anomala $+\mathrm{CP}$ & $0.125+1.25$ & $\mathrm{~ns}$ & $*$ & \# & $135.62 \dagger$ & \\
\hline D. anomala $+\mathrm{CP}$ & $0.25+1.25$ & ns & $*$ & \# & $318.21 \dagger$ & \\
\hline D. anomala + EMS & $0.0625+0.25$ & ns & $*$ & $\#$ & & $150.74+\dagger$ \\
\hline D. anomala + EMS & $0.125+0.25$ & $\mathrm{~ns}$ & $\mathrm{nt}$ & \# & & $158.37+\dagger$ \\
\hline D. anomala + EMS & $0.25+0.25$ & ns & $*$ & $\#$ & & $69.55 \dagger$ \\
\hline C. album & 0.078 & ns & $\mathrm{nt}$ & ngt & & \\
\hline C. album & 0.156 & ns & $\mathrm{nt}$ & ngt & & \\
\hline C. album & 0.313 & $\mathrm{~ns}$ & $*$ & ngt & & \\
\hline C. album $+\mathrm{CP}$ & $0.078+1.25$ & ns & $*$ & ngt & $-54.18 \ddagger$ & \\
\hline C. album $+\mathrm{CP}$ & $0.156+1.25$ & ns & $*$ & ngt & $-67.36 \$$ & \\
\hline C. album + CP & $0.313+1.25$ & ns & $*$ & ngt & $-56.40 \ddagger$ & \\
\hline C. album + EMS & $0.078+0.25$ & ns & $*$ & ngt & & $-49.72 \ddagger$ \\
\hline C. album + EMS & $0.156+0.25$ & ns & $*$ & ngt & & $-60.13 \ddagger$ \\
\hline C. album + EMS & $0.313+0.25$ & ns & $*$ & $\#$ & & $237.75+\dagger$ \\
\hline C. sinensis & 0.1094 & $\mathrm{~ns}$ & $\mathrm{nt}$ & ngt & & \\
\hline C. sinensis & 0.2085 & ns & nt & ngt & & \\
\hline C. sinensis & 0.44 & $\mathrm{~ns}$ & $\mathrm{nt}$ & ngt & & \\
\hline C. sinensis $+\mathrm{CP}$ & $0.1094+1.25$ & ns & $\mathrm{nt}$ & ngt & $-62.61 \%$ & \\
\hline C. sinensis $+\mathrm{CP}$ & $0.2085+1.25$ & ns & $\mathrm{nt}$ & ngt & $-65.62 \ddagger$ & \\
\hline C. sinensis + CP & $0.44+1.25$ & ns & $\mathrm{nt}$ & ngt & $-77.64 \$$ & \\
\hline C. sinensis + EMS & $0.1094+0.25$ & ns & $*$ & $\#$ & & $125.97 \dagger$ \\
\hline C. sinensis + EMS & $0.2085+0.25$ & ns & $\mathrm{nt}$ & $\#$ & & $5.48 \dagger$ \\
\hline C. sinensis + EMS & $0.44+0.25$ & ns & $*$ & \# & & $111.52 \dagger$ \\
\hline
\end{tabular}

$\mathrm{TC}=$ Test compound; GT $=$ genotoxicity; $(\mathrm{P}+\mathrm{M}) / \mathrm{A}+\mathrm{T})=($ Prophase + Methaphase $) /($ Anaphase + Telophase $) ; \mathrm{ns}=$ $(\mathrm{P}+\mathrm{M}) / \mathrm{A}+\mathrm{T})$ of treatment not significantly different from negative control; $\mathrm{CP}=$ Cyclophosphamide; $\mathrm{EMS}=$ Ethylmethane sulphonate; $\mathrm{PE}=$ Plant extract; $\mathrm{MI}=$ Mitotic index; $*=\mathrm{TC}$ is toxic $(\mathrm{MI}$ treatment significantly different from negative control, $\mathrm{P}<0.05$ in the t-test, $\mathrm{n}=3$ ); $\mathrm{nt}=\mathrm{TC}$ is not toxic; \# $=\mathrm{TC}$ is genotoxic (significant difference from negative control, $\mathrm{P}<0.05$ in the t-test, $\mathrm{n}=3$ ); $\uparrow=\mathrm{PE}+$ Mutagen mixture more genotoxic than mutagen alone but more or less than PE alone; $+\uparrow=\mathrm{PE}+$ Mutagen mixture more genotoxic than mutagen or PE alone; $+=\mathrm{PE}+$ Mutagen mixture less genotoxic than mutagen alone (reduction of genotoxicity) but more or less than PE alone; $+\$=\mathrm{PE}+$ Mutagen mixture less genotoxic than mutagen or PE alone.

In Table 4, of the three concentrations $\left(0.078,0.156,0.313 \mathrm{mg} \mathrm{mL}^{-1}\right)$ of Chenopodium album tested, the lower concentrations were not cytotoxic nor genotoxic when compared to the negative control. The highest concentration was cytotoxic but not genotoxic to the onion root meristem cells. Ethanolic extracts of leaves of $C$. album showed antimicrobial activities against Escherichia coli, Salmonella typhimurium, Staphylococcus aureus, Proteus vulgaris and Pseudomonas aeruginosa (Singh et al., 2011) and Bacillus subtilis with $13 \mathrm{~mm}$ of inhibition zone (Korcan et al., 2013). In one study, methanolic extracts of C. album and eight other South African medicinal plant species were not mutagenic to S. typhimurium (TA 98) in the Ames test (Mudzwiri, 2007). In a study by Khoobchandani et al. (2009), methanolic extract of leaves of C. album demonstrated anticancer activity 
against the estrogen dependent human breast cancer cell line (MCF-7) with an IC (50) of $27.31 \mathrm{mg} \mathrm{mL}^{-1}$. In the present study, it was the highest concentration $\left(0.313 \mathrm{mg} \mathrm{mL}^{-1}\right)$ that was cytotoxic but not genotoxic to the onion root meristem cells. The mixture of CP $\left(1.25 \mathrm{mg} \mathrm{mL}^{-1}\right)$ with each of the three concentrations of extracts of $C$. album separately was cytotoxic to the onion root tip meristem cells. However, none of the mixtures was genotoxic even though $\mathrm{CP}$ alone was genotoxic. By comparison, the mixures of $\mathrm{CP}$ with the C. album extracts were less genotoxic than $\mathrm{CP}$ alone $(55.18,68.36$ and $57.40 \%$ reduction) respectively. These observations suggested a reduction of CP-induced genotoxicity (antigenotoxic effect) by the extracts of C. album. In a study in vitro, the aqueous and methanolic extracts of $C$. album $\left(3,6,9 \mathrm{mg} \mathrm{mL}^{-1}\right)$ reduced the frequency of chromosome aberrations induced by $\mathrm{CP}\left(100 \mu \mathrm{g} \mathrm{mL}^{-1}\right)$ in a dose dependent manner in human lymphocytes but the extracts alone were not genotoxic (Panigrahy et al., 2011). The present results thus corroborate the results of Panigrahy et al. (2011) cited above. In mice, an increase in the anticlastogenic activity of CP-induced clastogenicity by $\beta$-carotene at lower doses and an absence of a protective effect at higher concentrations were observed (Salvadori et al., 1992). Salvadori et al. (1992) interpreted the observations to mean different mechanisms of $\beta$-carotene modulation and a possible alteration of the balance of $\mathrm{CP}$ activation/detoxification mechanism of the promutagen. The mixtures of EMS $\left(0.25 \mathrm{mg} \mathrm{mL}^{-1}\right)$ with the extracts of $C$. album were cytotoxic with the mixture of EMS and the highest concentration being also genotoxic. By comparison the mixures were less genotoxic than EMS alone (50.72 and $61.13 \%$ reduction) respectively. However, the mixture of EMS with the highest concentration was more genotoxic than EMS alone $(236.75 \%$ increase). These observations suggested a reduction of EMS-induced genotoxicity (antigenotoxic effect) by low concentrations of C. album extract but a synergistic interaction between C. album extract and EMS at high concentrations. These kinds of complex interactions between plant extracts and known mutagens have been reported. For instance, Rhizome juice of ginger was found to be antimutagenic against 6-gingerol-induced mutagenesis (Nakamura \& Yamamoto, 1982). However, when the juice was added to known mutagens such as AF-2 and MNNG, mugagenesis was increased by the ginger juice, and the potent mutagen identified in this case was 6-gingerol (Nakamura \& Yamamoto, 1982). The interpretation was that ginger juice containd antimutagenic substances that can suppress the activity of 6-gingerol and that, in the presence of certain specific mutagens like AF-2 and MNNG, 6-gingerol is able to express its mutagenicity (Nakamura \& Yamamoto, 1982). We are not inferring that a compound of like nature is present in the C. album extract only that the kinetics of action are similar.

Examination of the results of tests with Camellia sinensis in Table 4 shows that, the three concentrations $(0.1094$, $\left.0.2085,0.44 \mathrm{mg} \mathrm{mL}^{-1}\right)$ of $C$. sinensis tested did not significantly reduce the MI $(\mathrm{P}>0.05)$ when compared to the negative control and were therefore adjudged not cytotoxic. The concentrations did not also induce significant increases in the frequency of chromosome aberrations and were adjudged not genotoxic, when compared to the negative control. The mixture of $\mathrm{CP}\left(1.25 \mathrm{mg} \mathrm{mL}^{-1}\right)$ with each of the three concentrations of extract of $C$. sinensis separately was not cytotoxic and not genotoxic to the onion root tip meristem cells. By comparison, the mixures of $\mathrm{CP}$ with each of the three different concentrations of $C$. sinensis extracts were less genotoxic than $\mathrm{CP}$ alone $(63.61,66.62$ and $78.64 \%$ reduction) respectively. These observations suggested a reduction of CP-induced genotoxicity (antigenotoxic effect) by the tested concentrations of extracts of $C$. sinensis. The inhibition of the mutagenicity of known mutagens by plant extracts, which by themselves are not mutagenic, is a well-known phenomenon. For instance the spice, turmeric (Curcuma longa $\mathrm{L}$ ) and its yellow pigment, curcumin, were non-mutagenic but a diet that included $1 \%$ turmeric reduced benzo(a)pyrene (BaP)-and DMBA-induced stomach tumours and spontaneous mammary tumours in mice (Nagabhushan \& Bhide, 1985; Nagabhushan et al., 1987a; Nagabhushan et al., 1987b) and curcumin inhibited the mutagenicity of benzo[a]pyrene and dimethyl benzo[a] anthracene in a dose-dependent manner in Salmonella typhimurium strain TA98 in the presence of S-9 mix (Nagabhushan et al., 1987a). The observations were interpreted to mean that curcumin may alter the metabolic activation and detoxification of mutagens (Nagabhushan et al., 1987a). Extracts of green and black tea leaves decreased MNNG -induced mutagenicity in E. coli WP2 in vitro (Jain et al., 1987). Constituents of complex mixtures of plant origin, including tea and coffee, namely, caffeic, chloregenic, ellagic, ferulic, gallic and tannic acids and vitamin $\mathrm{C}$ have been shown to inhibit the mutagenicity of direct-acting $\mathrm{N}$-nitroso compounds, and vitamin A inhibited metabolic activation of promutagenic nitrosamines (Ames, 1982; Gichner \& Veleminsky, 1988). The mechanisms by which crude vegetable and fruit extracts reduce the cytotoxic effects of various clastogens may be different for different plants. The extracts of cruciferous plants such as Brussels sprouts, cabbage, cauliflower and broccoli have been shown to be capable both of activating enzymes such as arylhydrocarbon hydroxylase and of detoxifying enzymes such as the cytosolic GSH S-transferase (Debisri \& Archana, 1986). It has been reported that intake of diets containing powdered preparations of Brussels sprouts, cabbage, coffee beans, or tea leaves increased the activity of glutathione-S-transferase (GST), which catalyses the binding of electrophiles to glutathione (GSH) (Sparnins et al., 1982). It has therefore been suggested that 
GST activated by vegetables juices may be involved in the anticlastogenic activity of the vegetables (Debisri \& Archana, 1996) and that the mechanisms of the inhibition of metabolic activation of indirectly acting mutagens may be by the inactivation of metabolizing enzymes or interaction with promutagens to make them unavailable for the enzymatic process (Hayatsu et al., 1988). The mixtures of CP and extracts of $C$. sinensis were not genotoxic in the present study. The mixture of EMS $\left(0.25 \mathrm{mg} \mathrm{mL}^{-1}\right)$ with $0.1094 \mathrm{mg} \mathrm{mL}^{-1}$ (lowest concentration) or $0.44 \mathrm{mg} \mathrm{mL}^{-1}$ (highest concentration) of extract of $C$. sinensis reduced the mitotic index of onion root tip cells significantly $(\mathrm{P}<.05)$ compared to the negative control and were adjudged to be cytotoxic. The mixture of EMS $\left(0.25 \mathrm{mg} \mathrm{mL}^{-1}\right)$ with $0.2085 \mathrm{mg} \mathrm{mL}^{-1}$ (middle concentration of $C$. sinensis extract) did not significantly reduce the MI the root tip cells $(\mathrm{P}>05)$ compared to the negative control and was adjudged not cytotoxic. The cytotoxicity was therefore not concentration dependent. However, the mixtures of EMS with the different concentrations of extracts of $C$. sinensis were more genotoxic than EMS alone (124.97, 4.48 and $110.52 \%$ increase). This observation suggested a potentiation of the genotoxic activity of EMS by extracts of $C$. sinensis. Such potentiating effects of activities of mutagens by plant extracts, which alone are not mutagenic, are common. For example, while small doses of Angelicae radix and Cnidii rhizome extracts enhanced the mutagenicity of benzo(a)pyrene (BaP), at higher doses a decreasing effect was observed (Sakai et al., 1988). In the present study, extracts of $C$. sinensis were not genotoxic but when mixed with the direct acting mutagen EMS, the mixtures were more genotoxic than the EMS alone.

MI measures the proportion of cells in the M-phase of the cell cycle and therefore its inhibition could be interpreted as cellular death or a delay in the cell mitotic activities (Rojas et al., 1993), which, according to Sudhakar et al. (2001) could be due to inhibition of DNA synthesis or a blocking in the G2 phase of the cell cycle, thereby preventing the cell from entering mitosis. Many herbal extracts have been reported to inhibit mitosis (Çelik \& Aslantürk 2006; Çelik \& Aslantürk 2007; Akinboro \& Bakare, 2007). In the present study, methanolic extracts of $D$. anomala and the highest concentration of $C$. album decreased the MI in treated A. cepa roots. The present results therefore suggested that the tested concentrations of extracts of Dicoma anomala (root) and Chenopodium album (leaves) exerted mito-depressive or cytotoxic effects on cell division of A. cepa root meristem cells which could be attributed the effects of compounds present in the extracts.

The aberrant dividing cells observed and scored in the present study were sticky chromosomes (S) and c-mitosis (C-Mit) following treatments with $D$. anomala; sticky chromosomes (S), c-mitosis (C-Mit), chromosome largards (L)., anaphase and telophase bridges (A.B) and chromosome breaks following treatments with C. album or $C$. sinensis mixture with EMS. The levels of inductions of the aberrant cells were however not significant when compared to the negative control, following treatments with extracts of C. album or C. sinensis.

Sticky chromosomes, lose their normal appearance, and seen with sticky "surface," which cause cluster (Babich et al., 1997). Stickiness has been attributed to the effect of pollutants and chemical compounds on the physical and chemical properties of DNA, protein or both, on the formation of complexes with phosphate groups in DNA, on DNA condensation or on formation of inter- and intra-chromatid cross links (Shahin \& El-Amoodi, 1991; Rencüzoğullari, et al., 2001; El-Ghamery et al., 2003; Gömürgen, 2005; T"urkoglu, 2007). The presence of chromosome fragments is an indication of chromosome breaks, and can be a consequence of anaphase/telophase bridges (Sharma \& Sen, 2002; Singh, 2003). Levan (1938) described colchicine mitosis (c-metaphase or $\mathrm{c}$-anaphase) as an inactivation of the spindle followed by a random scattering of the condensed chromosomes in the cell. According to Mustafa \& Arikan (2008), a large number of laggard chromosomes and c-anaphases indicate that a test compound acted as a potent spindle inhibitor. The induction of vagrant chromosomes according to Elghamery et al. (2003), leads to the separation of unequal number of chromosomes in the daughter nuclei and subsequently formation of daughter cells with unequal sized or irregularly shaped nuclei at interphase. In the present study, the treatments of root tips with $D$. anomala and to, insignificant level, $C$ album and $C$. sinensis induced c-mitosis in the onion root tip meristem cells. Thus the frequencies of total chromosome aberrations increased significantly upon exposure to $D$. anomala, mixtures of $D$. anomala with CP or EMS, the mixture of highest concentration of $C$. album with EMS and mixtures of $C$. sinensis with EMS. These results are in agreement with the results of some other studies which examined the effects of different medicinal herbs (Soliman, 2001; Bidau et al., 2004).

The ratio of dividing cells in prophase and metaphase to those in anaphase and telophase i.e. $(\mathrm{P}+\mathrm{M}) /(\mathrm{A}+\mathrm{T})$ has been used as indicator of metaphase arrest. A decrease in the proportion of dividing cells in $\mathrm{A}+\mathrm{T}$ is an indication of metaphase arrest due to the poisoning of the spindle fibers, akin to the action of the well documented spindle poison, colcemid (Parry et al., 1999). In the present study the relative proportions of $\mathrm{P}+\mathrm{M}$ and $\mathrm{A}+\mathrm{T}$ types did not differ significantly when compared to the negative control following treatment of the onion root tips with extracts of the individual plant species, the individual mixtures of the extracts with the mutagens or the mutagens 
alone. The observation suggested that the plant extracts did not contain appreciable concentrations of spindle poisons. However, very few c-mitosis (C-Mit) cells were observed on the prepared slides. In a study of Parry et al. (1999), treatment of a pulmonary cell line derived from the Chinese hamster and designated DON: Wg3H resulted in decrease in the $\mathrm{MI}$ with increased dose but, the relative proportions of $\mathrm{P}+\mathrm{M}$ and $\mathrm{A}+\mathrm{T}$ types remained the same. In the present study too, the MI of treated root meristem cells decreased following certain treatments but the relative proportions of $\mathrm{P}+\mathrm{M}$ and $\mathrm{A}+\mathrm{T}$ types remained the same. The observation was taken as a typical indicator of cytotoxic damage (Parry et al., 1999).

Working with crude extracts means working with complex mixtures of biologically active compounds, some of which can be cytotoxic and/or genotoxic; others can be cytoprotective and/or antigenotoxic. The results suggest that, although $D$. anomala and $C$ album have beneficial effects as medicinal plants, they can cause serious problems and damage on cells if they are improperly used.

\section{Conclusion}

The tested concentrations of $D$. anomala $\left(0.0625,0.125,0.25 \mathrm{mg} \mathrm{mL}^{-1}\right)$, were cytotoxic and genotoxic. Mixture of CP with the lowest concentration of $D$. anomala was more genotoxic than CP $(250.50 \%$ increase $)$ or $D$. anomala extract alone. The mixtures of EMS with the lower concentrations of $D$. anomala extract were more genotoxic than EMS (149.74 and $157.37 \%$ increases) or D. anomala extract alone. The lower concentrations of C. album extract were not cytotoxic and all the three concentrations $\left(0.078,0.156,0.313 \mathrm{mg} \mathrm{mL}^{-1}\right)$, were not genotoxic. The mixtures of $\mathrm{CP}$ with extracts of $C$. album were cytotoxic. CP-induced genotoxicity was reduced (55.18, 68.36 and $57.40 \%$ reductions) by the C. album extracts. EMS-induced genotoxicity was reduced (50.72 and $61.13 \%$ reductions) by low concentrations but increased by the highest concentration $(236.75 \%$ increase) which suggested antigenotoxicity and synergism respectively. The tested concentrations of $C$. sinensis and the mixtures of $\mathrm{CP}$ with $C$. sinensis extracts were not cytotoxic and not genotoxic. However, CP-induced genotoxicity was reduced $(63.61,66.62,78.64 \%)$ while EMS-induced genotoxicity was increased $(124.97,4.48$ and $110.52 \%$ ) by extracts of $C$. sinensis. The frequencies of total chromosome aberrations increased significantly upon exposure to $D$. anomala, mixtures of $D$. anomala with CP or EMS, the mixture of $0.313 \mathrm{mg}$ $\mathrm{mL}^{-1}$ concentration of $C$. album with EMS and mixtures of $C$. sinensis with EMS. The $(\mathrm{P}+\mathrm{M}) /(\mathrm{A}+\mathrm{T})$ ratios did not differ significantly $(\mathrm{P}>0.05)$ following the treatments.

\section{References}

Abraham, S., \& Cherian, V. D. (1978). Studies on cellular damage by extracts of betel leaves used for chewing. Cytologia, 43, 203-208. http://dx.doi.org/10.1508/cytologia.43.203

Adedapo, A. A., Jimoh, F. O., Afolayan, A. J., \& Masika, P. J. (2009). Antioxidant properties of methanol extracts of the leaves of Celtis Africana, Records of Natural Products, 3(1), 23-31.

Akeem, A., Mohamed, K. B., Asmawi, M. Z., \& Sofiman, O. A. (2011). Mutagenic and antimutagenic potentials of fruit juices of five medicinal plants in Allium cepa L.: Possible influence of DPPH free radical scavengers. African Journal of Biotechnology, 10(51), 10520-10529. http://www.academicjournals.org/AJB http://dx.doi.org/10.5897/AJB11.694

Akinboro, A., \& Bakare, A. A. (2007). Cytotoxic and genotoxic effects of aqueous extracts of five medicinal plants. Journal of Ethnopharmacology, 112(3), 470-475. doi:10.1016/j.jep.2007.04.014

Alisi, C. S., Ojako, O. A., Osuagwu, C. G., \& Onyeze, G. O. C. (2011). Free radical scavenging and in vitro antioxidant effects of ethanol extract of the medicinal herb Chromolaena odorata Linn. British Journal of Pharmaceutical Research, 1(4), 141-155.

Ames, B. N. (1982). Mutagens in our environment. Alan R. Liss, New York.

Ames, B. N. (1986). Food constituents as a source of mutagens, carcinogens and anticarcinogens. In I. Knudsen (Ed.), Genetic Toxicology of the Diet (pp. 55-62). Alan R. Liss, New York, NY, USA.

Ames, B. N., Shigenaga, M. K., \& Hagen, T. M. (1993). Oxidants, Antioxidants, and the Degenerative Diseases of Aging, Proceedings of the National Academy of Sciences, U.S.A, 90(17), 7915-7922.

Asita, A. O., \& Makhalemele, R. (2008). Genotoxicity of Chlorpyrifos, Alpha-thrin, Efekto virikop and Springbok to onion root tip cells, African Journal of Biotechnology, 7(23), 4244-4250. http://dx.doi.org/ 10.5897/AJB08.550.

Aydemir, N., Çelikler, S., Summak, S., Yılmaz, D., \& Özer, Ö. (2008). Evaluation of clastogenicity of 4,6-Dinitro-ocresol (DNOC) in Allium root tip test. Journal of Biodiversity and Environmental Sciences, 2(5), 59-63. 
Babich, H., Segall, M. A., \& Fox, K. D. (1997). The Allium test- a simple, eukaryote genotoxicity assay. American Biology Teacher, 59(9), 580-583.

Bailey, L. H. (1949). Manual of cultivated plants. Most commonly grown in the continental United States and Canada (Rev.ed., completely restudied). NewYork: Macmillan. Retrieved from http://trove.nla.gov.au/ version $/ 45838603$

Basaran, A. A., Yu T.-W., Plewa M. J., \& Anderson, D. (1996). An investigation of some Turkish herbal medicines in Salmonella typhimurium and in the COMET assay in human lymphocytes. Teratogenesis Carcinogenesis and Mutagenesis, 16(2), 125-138. http://dx.doi.org/10.1002/(SICI)1520-6866(1996) 16:2<125::AID-TCM6>3.3.CO;2-C

Baumann, F., \& Preiss, R. (2001). Cyclophosphamide and related anticancer drugs. Journal of Chromatography B: Biomedical Sciences and Applications, 764(1-2), 173-192. doi:10.1016/S0378-4347(01)00279-1

Becker, J. V. W., van der Merwe, M. M., van Brummelen, A. C., Pillay, P., Crampton, B. G., Mmutlane, E. M., ... Maharaj, V. J. (2011). In vitro anti-plasmodial activity of Dicoma anomala subsp. gerrardii (Asteraceae): identification of its main active constituent, structure-activity relationship studies and gene expression profiling. Malaria Journal, 10, 295-305.

Bidau, C. J., Amat, A. G., Yajia, M., Marti, D. A., Riglos, A. G., \& Silvestroni, A. (2004). Evaluation of the genotoxicity of aqueous extracts of Ilex paraguariensis St. Hil. (Aquifoliaceae) using the Allium test. Cytologia, 69(2), 109-117. http://doi.org/10.1508/cytologia.69.109

Bökel, C. (2008). EMS screens: from mutagenesis to screening and mapping. Methods in Molecular Biology, 420, 119- 138. http://dx.doi.org/10.1007/978-1-59745-583-1_7

Boyer, J., \& Liu, R. H. (2004). Apple phytochemicals and their health benefits. Nutrition Journal, 3, 5-22 doi:10.1186/1475-2891-3-5

Brito, M. T., Martinez, A., \& Cadavid, N. F. C. (1990). Mutagenic activity in regional foods and beverages from the Venezuelan Andean region. Mutation Research, 243 (2), 115-120. doi:10.1016/0165-7992(90)90032-F

Buřičova, L., \& Reblova, Z. (2008). Czech medicinal plants as possible sources of antioxidants. Czech Journal and Food Sciences, 26, 132-138.

Cauhan, L. K. S., Saxena, P. N., \& Gupta, S. K. (1999). Cytogenetic effects of cypermetrin and fenvalerate on the root meristem cells of Allium cepa, Environmental and Experimental Botany, 42(3), 181-189. doi:10.1016/S0098-8472(99)00033-7

Çelik, T. A., \& Aslantürk, Ö. S. (2007). Cytotoxic and genotoxic effects of Lavandula stoechas aqueous extracts. Biologia Bratislava, 62(3), 292-296. DOI:10.2478/s11756-007-0051-2

Çelik, T. A., \& Aslantürk, Ö. S. (2006). Anti-mitotic and antigenotoxic effects of Plantago lanceolata aqueous extract on Allium cepa root tip meristem cells. Biologia, 61(6), 693-697. DOI:10.2478/s11756-006-0142-5

Çelik, T. A., \& Aslantürk, Ö. S. (2010). Evaluation of Cytotoxicity and Genotoxicity of Inula viscosa Leaf Extracts with Allium Test. Journal of Biomedicine and Biotechnology, 2010, 1-9. doi:10.1155/2010/189252

Constantin, M. J., \& Owen, E. T. (1982). Introduction and perspectives of plant genetic and cytogenetic assay, A report of US EPA Gene-Tox programme, Mutation Research, 99, 1-12.

Cutillo, F., D’Abrosca, B., DellaGreca, M., \& Zarrelli, A. (2004). Chenoalbicin, a novel cinnamic acid amide alkaloid from Chenopodium album. Chemistry and Biodiversity, 1(10), 1579-1583. http://dx.doi.org/10.1002/cbdv.200490118

de Sá Ferreira, I. C. F., \& Ferrão Vargas, V. M. F. (1999). Mutagenicity of medicinal plant extracts in Salmonella/microsome assay. Phytotherapy Research, 13(5), 397-400. http://dx.doi.org/10.1002/(SICI) 1099-1573(199908/09)

Debisri, S., \& Archana, S. (1996). Medicinal plants and Genetic toxicology Research: The Botanical Review Publisher: New York Botanical Garden Audience, 62 (4),. COPYRIGHT 1996 New York Botanical Garden ISSN: 0006-8101.

DellaGreca, M., D’Abrosca, B., Fiorentino, A., Previtera, L., \& Zarrelli, A. (2005a) Structure elucidation and phytotoxicity of ecdysteriods from Chenopodium album. Chemistry and Biodiversity, 2(4), 457-462. http://dx.doi.org/10.1002/cbdv.200590025 
DellaGreca, M., Di Mariono, C., Zarrelli, A., \& D'Abrosca, B. (2004). Isolation and phytotoxicity of apocarotenoids from Chenopodium album. Journal of Natural Products, 67(9), 1492-1495. http://dx.doi.org/10.1021/np049857q

DellaGreca, M., Previtera, L., \& Zarrelli, A. A. (2005b). New xyloside from Chenopodium album. Natural Product Research, 19(1), 87-90. DOI:10.1080/14786410410001686391

Dinan, L. (1992). The analysis of phytoecdysteroids in single (preflowering stage) specimens of fat hen, Chenopodium album. Phytochemical Analysis, 3(3),132-138. http://dx.doi.org/10.1002/pca.2800030309

Dinan, L., Whiting, P., \& Scott, A. J. (1998). Taxonomic distribution of phytoecdysteroids in seeds of members of the chenopodiaceae. Biochemical Systematics and Ecology, 26(5), 553-76. h10.1016/S03051978(98)00005-2

El-Ghamery, A. A., El-Kholy, M. A., \& El-Yousser, M. A. A. (2003). Evaluation of cytological effects of Zn2+ in relation to germination and root growth of Nigella sativa L. and Triticum aestivum L.. Mutation Research, 537, 29-41.

Fiskesjö, G. (1985). The Allium test as a standard in environmental monitoring. Hereditas, 102(1), 99-112.

Gichner, T., \& Velemínský, J. (1988). Mechanisms of inhiobition of N-nitroso compounds-induced mutagenicity. Mutation Research, 202(2), 325-334. doi:10.1016/0027-5107(88)90195-9

Gimmler-Luz, M. C., Cardoso, V. V., Sardiglia, C. U., \& da Silva Widholzer D. (1999). Transplacental inhibitory effect of carrot juice on the clastogenicity of cyclophosphamide in mice, Genetics and Molecular Biology, 22(1),1-13. http://dx.doi.org/10.1590/S1415-47571999000100013

Gohar, A. A., \& Elmazar, M. M. A. (1997). Isolation of hypotensive flavonoids from Chenopodium species growing in Egypt. Phytotherapy Research, 11(8), 564-567. http://dx.doi.org/10.1002/(SICI)1099-1573 (199712)11:8<564::AID-PTR162>3.0.CO;2-L

Gömürgen, A. N. (2005). Cytological effect of the potassium metabisulphite and potassium nitrate food preservative on root tips of Allium cepa L.. Cytologia, 70(2), 119-128. http://doi.org/10.1508/cytologia. 70.119

Grant, W. F. (1982). Chromosome aberration assays in Allium. A report of the U.S. Environmental Protection Agency Genotox Program, Mutation Research, 99(3), 273-291. http://dx.doi.org/10.1016/0165-1110 (82) $90046-X$

GRIN Database USDA, ARS. (2005). National Genetic Resources Program, Germplasm Resources Information Network (GRIN), National Germplasm Research Laboratory, Beltsville, Maryland. Retrieved from http://www.ars-grin.gov2/cgibin/ npgs/html/genform.pl

Gupta, S., Saha, B., \& Giri, A. K. (2002). Comparative antimutagenic and anticlastogenic effects of green tea and black tea: a review, Mutation Research, 512(1), 37-65. doi:10.1016/S1383-5742(02)00024-8

Gwaza, L., Wolfe, A. R., Benet, L. Z., Guglielmo, B. J., Chagwedera, T. E., Maponga, C. C., \& Masimirembwa, C. M. (2009). In vitro inhibitory effects of Hypoxis obtusa and Dicoma anomala on cyp450 enzymes and pglycoprotein. African Journal of Pharmacy and Pharmacology, 3(11), 539-546.

Hales, B. E. (1982). Comparison of the mutagenicity and teratogenicity of cyclophosphamide and its active metabolites, 4 hydroxycyclophosphamide, phosphoramide mustard and acrolein. Cancer Research, 42, 3016-3021.

Hartwell, J. L. (1967). Plants used against cancer. A survey. Lloydia, 30, 379-436.

Hayatsu, H., Arimoto, S., \& Negishi, T. (1988). Dietary inhibitors of mutagenesis and carcinogenesis. Mutation Research, 202(2), 429-446. doi:10.1016/0027-5107(88)90204-7

Higashi, K. (1988). Metabolic activation of environmental chemicals by microsomal enzymes of higher plants. Mutation Research, 197(2), 273-288. doi:10.1016/0027-5107(88)90098-X

Higashimoto, M., Purintrapiban, J., Kataoka, K., Kinouchi, T., Vinitketkumnuen, U., Akimoto, S., Matsumoto, H., \& Ohnishi, Y. (1993). Mutagenicity and antimutagenicity of extracts of three spices and a medicinal plant in Thailand. Mutation Research, 303(3), 135-142. doi:10.1016/0165-7992(93)90026-R

Horio, T., Yoshida, K., Kikuchi, H., Kawabata, J., \& Mizutani, J. (1993). A phenolicamide from roots of Chenopodium album, Phytochemistry, 33, 807-808. http://dx.doi.org/10.1016/0031-9422(93)85278-Y 
Jain, A. K., Shimoi, K., Nakamura, Y., Tomita, I., \& kada, T. (1987). Preliminary study on the desmutagenic and antimutagenic effect of some natural products. Current science, 56(19), 1266-1269.

Joshipura, K. J., Hu, F. B., Manson, J. E., Stampfer, M. J., Rimm, E. B., Speizer, F. E., ... Willet, W. C. (2001). The effect of fruit and vegetable intake on risk of coronary heart disease. Annals of Internal Medicine, 134 (12), 1106-1114. doi:10.7326/0003-4819-134-12-200106190-00010

Kassie, F., Parzefall, W., Musk, S., Johnson, I., Lamprecht, G., Sontag, G., \& Knasmüller, S. (1996). Genotoxic effects of crude juices from Brassica vegetables and juices and extracts from phytopharmaceutical preparations and spices of cruciferous plants origin in bacterial and mammalian cells. Chemico-Biological Interactions, 102(1), 1-16. doi:10.1016/0009-2797(96)03728-3

Kazembe, T., \& Chinyuku, J. (2012). In vitro Babeosis Assaying using Acacia karroo and Dicomaanomala Plant Extracts and Extract Fortified Antimalarial Drugs. Bulletin of Environment, Pharmacology and Life Sciences, 1(9), 26 - 31.

Khaidakov, M., Bishop, M. E., Manjanatha, M. G., Lyn-Cook, L. E., Desai, V. G., Chen, J. J., \& Aidoo, A. (2001). Influence of dietary antioxidants on the mutagenicity of 7,12-dimethylbenz[a]anthracene and bleomycin in female rats. Mutation Research, 480-481(1), 163-170 doi:10.1016/S0027-5107(01)00180-4.

Khoobchandani, M., Ojeswi, B. K., Sharma, B., \& Srivastava, M. M. (2009). Chenopodium album prevents progression of cell growth and enhances cell toxicity in human breast cancer cell lines. Oxidative Medicine and Cellular Longevity, 2(3), 160-165.

Korcan, S. E., Aksoy, O., Erdogmus, S. F., Cigerci, I. H., \& Konuk, M. (2013). Evaluation of antibacterial, antioxidant and DNA protective capacity of Chenopodium album's ethanolic leaf extract. Chemosphere, 90(2), 374-379. http://dx.doi.org/10.1016/j.chemosphere.2012.07.030

Leme, M. D., \& Marin-Morales, M. A. (2008). Chromosome aberration and micronucleus frequencies in Allium cepa cells exposed to petroleum polluted water - A case study. Mutation Research, 650(1), 80-86. http://dx.doi.org/10.1016/j.mrgentox.2007.10.006

Leme, M. D., \& Marin-Morales, M. A. (2009). Allium cepa test in environmental monitoring: a review on its application. Mutation Research, 682 (1), 71-81. doi:10.1016/j.mrrev.2009.06.002

Levan, A. 1938. The effect of colhicine on root mitoses in Allium. Hereditas, 24, 471-486.

Luseba, D., Elgorashi, E. E., Ntloedibe, D. T., \& Van Staden, J. (2007). Antibacterial, anti-inflammatory and mutagenic effects of some medicinal plants used in South Africa for the treatment of wounds and retained placenta in livestock. South African Journal of Botany, 73(3), 378-383. http://dx.doi.org/10.1016/j.sajb. 2007.03.003

Mekki, L. (2014). Genoprotectivity of methanol and ethanol extracted leaf sap of Trigonella foenum-graecum in Allium cepa root assay. Acta Biologica Hungarica, 65(1), 85-95. http://dx.doi.org/10.1556/ABiol.65. 2014.1.8

Ming, T. L. (1992). A revision of Camellia sect. Thea. Acta Botanica Yunnanica, 14(2), 115-132.

Mohn, G. R., \& Ellenberger, J. (1976). Genetic effects of cyclophosphamide, ifosfamide and trofosfamide. Mutation Research, 32, 331-360.

Mudzwiri, M. (2007). Evaluation of traditional South African leafy plants for their safety in human consumption (Unpublished master's thesis). Durban University of Technology, Durban, South Africa.

Müller, L., Gocke, E., Lav'e, T., \& Pfister, T. (2009). Ethyl methanesulfonate toxicity in viracept-a comprehensive human risk assessment based on threshold data for genotoxicity. Toxicology Letters, 190(3), 317-329. http://dx.doi.org/10.1016/j.toxlet.2009.04.003

Mustafa, Y., \& Arikan, E. S. (2008). Genotoxicity testing of quizalofop-P-ethyl herbicide using the Allium cepa anaphase-telophase chromosome aberration assay. CARYOLOGIA, 61(1), 45-52. http://dx.doi.org/10. 1080/00087 114.2008.10589608

Nagabhushan, M., Amonkar, A. J., \& Bhide, S. V. (1987a). Mutagenicity of gingerol and shagaol and antimutagenicity of zingerone in Salmonella microsome assay. Cancer Letters, 36(2), 221-233. doi:10.1016/0304-3835(87)90094-2

Nagabhushan, M., Amonkar, A. J., \& Bhide, S. V. (1987b). In vitro antimutagenicity of curcumin against environmental mutagens. Food and Chemical Toxicology, 25(7), 545-547. 
Nagabhushan, M., \& Bhide, S. V. (1985). Mutagenicity of chili extract and capsaicin in short-term tests. Environmental and Molecular Mutagenesis, 7(6), 881-8.

Nagao, M., Wakabayashi, K., Fujita, Y., Tahira, T., Ochiaia, T., \& Sugimura T. (1986). Mutagenic compounds in soy sauce, Chinese cabbage, coffee and herbal teas. In I. Knudsen (Ed.), Genetic Toxicology of the Diet (pp. 55-62). Alan R. Liss, New York, NY, USA.

Nakamura, H., \& Yamamoto, T. (1982). Mutagen and anti-mutagen in ginger, Zingiber officinale. Mutation Research, 103(2), 119-126. doi:10.1016/0165-7992(82)90016-1

Ndhlala, A. R., Aderogba, M. A., Ncube, B., \& Van Staden, J. (2013). Anti-oxidative and cholinesterase inhibitory effects of leaf extracts and their isolated compounds from two closely related Croton species. Molecules, 18, 1916-1932.

Nguyen, T., Fluss, L., Hodej, R., Ginther, G., \& Leighton T. (1989). The distribution of mutagenic activity in red rose and white wines. Mutation Research, 223(2), 205-212. doi:10.1016/0165-1218(89)90048-7

Panigrahy, S. K., Jatawa, S., \& Tiwari, A. (2011). Modulatory effect of chenopodium album extract against cyclophosphamide induced genotoxicity damage in cultured mammalian cells. International Journal of Pharmacy and Pharmaceutical Sciences, 4(1), 541-542.

Parry, E. M., Mumba, L. E., Asita, A., \& Parry, J. M. (1999). Mechanisms of Action of Aneuploidy Inducing Chemicals with Particular Reference to Spindle Inhibitors and Neurotoxins. In R. C. Sobti, G. Obe, \& P. Quillardet (Eds), Trends in environmental mutagenesis (pp. 101-110). Tausco Book distributors, New Delhi, India, Publisher.

Platzek, T., Bochert, G., \& Meister, R. (1995). Embryotoxicity induced by alkylating agents: 9. Low dose prenatal-toxic risk estimation of ethylmethanesulfonate based on no-observedadverse- effect-level risk factor approach, dose-response relationships, and molecular dosimetry. Teratogenesis Carcinogenesis and Mutagenesis, 15(2) 81-92.

Plewa, M. J., \& Gentile, J. M. (1982). The activation of chemical mutagens by Green plants. In A. Hollander, \& F. J. de Serres (Eds.), Chemical Mutagens, Principles and Methods for Their Detection (pp. 401-420). Plenum Vol. VII, New York.

Rencüzoğullari, E., İla, H. B., Kayraldiz, A., \& Topaktaş M. (2001). Chromosome aberrations and sister chromatid exchanges in cultured human lymphocytes treated with sodium metabisulfite, a food preservative. Mutation Research/Genetic Toxicology and Environmental Mutagenesis, 490(2), 107-112. doi:10.1016/S1383-5718(00)00142-X

Rojas, E., Herrera, L. A., Sordo, M., Gonsebatt, M. E., Montero, R., Rodriguez, R., \& Ostrosky-Wegman, P. (1993). Mitotic index and cell proliferation kinetics for identification of antineoplastic activity. Anti-Cancer Drugs, 4(6), 637-640.

Sakai, Y., Nagase, H., Ose, Y., Sato, T., Kawai, M., \& Mizuno, M. (1988). Effects of medicinal plant extracts from Chinese herbal medicines on the mutagenic activity of benzo(a)pyrene. Mutation Research, 206(3), 327-334. doi:10.1016/0165-1218(88)90118-8

Salvadori, D. M. F., Ribeiro, L. R., Oliveira, M. D. M., Pereira, C. A. B., \& Beçak, W. (1992). The protective effect of $\beta$-carotene on genotoxicity induced by cyclophosphamide. Mutation Research, 265(2), 237-244. doi:10.1016/0027-5107(92)90052-4

Schimmer, O., Krüger, A., Paulini, H., Haefele, F. (1994). An evaluation of 55 commercial plant extracts in the Ames mutagenicity test. Pharmazie, 49(6), 448-451.

Sega, G. A. (1984). A review of the genetic effects of ethyl methanesulfonate. Mutation Research, 134(2-3), 113-142. doi:10.1016/0165-1110(84)90007-1

Shahin, S. A., \& El-Amoodi, K. H. H. (1991). Induction of numerical chromosomal aberrations during DNA synthesis using the fungicides nimrod and rubigan-4 in root tips of Vicia faba L.. Mutation Research, 261(3), 169-176. doi:10.1016/0165-1218(91)90064-S

Shale, T. L., Stirk, W. A., \& Van Staden, J. (1999). Screening of medicinal plants used in Lesotho for anti-bacterial and anti-inflammatory activity. Journal of Ethnopharmacology, 67, 347-354. doi:10.1016/S0378-8741(99)00035-5

Sharma, A., \& Sen, S. (2002). Chromosome Botany. Science, Enfield, NH, USA. 
Singh, K. P., Dwevedi, A. K., \& Dhakre, G. (2011). Evaluation of antibacterial activities of chenopodium album. International Journal of Applied Biology and Pharmaceutical Techonology, 2(3), 398-401.

Singh, R. J. (2003). Plant Cytogenetics. CRC Press, Boca Raton, Fla, USA.

Soliman, M. I. (2001). Genotoxicity testing of neem plant (Azadirachta indica A. Juss.) using the Allium cepa chromosome aberration assay. Journal of Biological Sciences, 1(11), 1021-1027. http://dx.doi.org/10.3923/jbs.2001.1021.1027

Sopova, M., Sekovski, Z., \& Jovanovska, M. (1983). Cytological effects of tobacco leaf extract on root-tip cells of Allium sativum. Acta Biol. Med. Exp. 8, 49-56.

Sparnins, V. L., Venegas, P. L., \& Wattenberg, L. W. (1982). Glutathione-S-transferase activity. Enhancement by compounds inhibiting chemical carcinogenesis and by dietary constituents. Journal of the National Cancer Institute, 68(3), 493-496. http://dx.doi.org/10.1093/jnci/68.3.493

Stubbs, L., Carver, E.A., Cacheiro, N. L., Shelby, M., \& Generoso, W. (1997). Generation and characterization of heritable reciprocal translocations in mice. Methods, 13(4), 397-408. doi:10.1006/meth.1997.0546

Sudhakar, R., Ninge Gowda, K. N., \& Venu, G. (2001). Mitotic abnormalities induced by silk dyeing industry effluents in the cells of Allium cepa. Cytologia, 66(3), 235-239. http://doi.org/10.1508/cytologia.66.235

Türkoğlu, Ş. (2007). Genotoxicity of five food preservatives tested on root tips of Allium cepa L.. Mutation Research/Genetic Toxicology and Environmental Mutagenesis, 626(1-2), 4-14. doi:10.1016/j.mrgentox. 2006.07.006

Willett, W. (2002). Balancing life-style and genomics research for disease prevention. Science, 296(5568), 695-698. http://dx.doi.org/10.1126/science.1071055

Wong, F. C., Chai, T. T., \& Hoo, Y. W. (2012). Antioxidation and cytotoxic activities of selected medicinal herbs used in Malaysia. Journal of Medicinal Plants Research, 6(16), 3169-3175. http://dx.doi.org/10.5897/JMPR11.1631

Woods, R. K., Walters, E. H., Raven, J. M., Wolfe, R., Ireland, P. D., Thien, F. C., \& Abramsom, M. J. (2003). Food and nutrient intakes and asthma risk in young adults. The American Journal of Clinical Nutrition, 78(3), 414-421.

Wynder, E. L., Hall, N. E. L., \& Polansky, M. (1983). Epidemiology of coffee and pancreatic cancer. Cancer Research, 43(8), 3900-3906.

Zink, T., \& Chaffin, J. (1998). Herbal health products: what family physicians need to know. American Family Physician, 58(5), 1133-1140.

Zuo, Y., Chen, H., \& Deng, Y. (2002). Simultaneous determination of catechins, caffeine and gallic acids in green, Oolong, black and pu-erh teas using HPLC with a photodiode array detector. Talanta, 57(2), 307-316. doi:10.1016/S0039-9140(02)00030-9

\section{Copyrights}

Copyright for this article is retained by the author(s), with first publication rights granted to the journal.

This is an open-access article distributed under the terms and conditions of the Creative Commons Attribution license (http://creativecommons.org/licenses/by/3.0/). 